\title{
THE DIPTEROUS GENUS DRAPETIS MEIGEN
}

\section{(Family Empididæ).*}

\author{
By A. L. Melander, \\ Pullman, Washington.
}

The species of Drapetis are to be distinguished from the remainder of the Empididæ by the following summarized combination of characters. Thorax robust, the humeri not swollen and constricted. Eyes closely approximate on the face, but on the front diverging above; palpi broad, incumbent on the very short proboscis; antennæ three-jointed, with terminal or subterminal arista; one pair each of vertical and ocellar bristles. Legs hairy and often furnished with bristles or setæ, the middle femora however rarely armed and not thicker than the front pair. First basal cell of the wings shorter than the second which is united with the discal cell, anal cell completely wanting, only two posterior cells before the anal area.

The genus Drapetis includes very small flies, among the smallest of all the Diptera, which are found during the spring and summer, sometimes swarming about flowers like wild cherry and plum, and sometimes running about singly over grass and low shrubbery. Their early stages are quite unknown. In the tropics slender yellow-colored species predominate but in the Temperate Zone the general species are black and more robust.

In the following pages are given a detailed discussion of the external morphology of the drapetine flies, a synoptic table to

* Contribution from the entomological laboratories of the Bussey Institution for Applied Biology, Harvard University. No. 149.

I) began a study of the Empididæ, a family of predatory dipterous flies. Since that time several papers dealing with the taxonomy of the family have appeared from his pen, notably a review of the North American species known up to 1902, which was published as a thesis for the master's degree. The accumulation of a wealth of material in this family, especially from the rich collecting fields of the Pacific North-west, led to the preparation of an exhaustive review of the group which was accepted by Harvard University in 1914 as the thesis requirement for the (legree of 1)octor of Science. It was the writer's intention to issue this manuscript of quite one thousand pages in the Genera Insectorum, but the outbreak and centralization of the war in Belgium entirely precluded this possibility. Since many of the new species have been distributed among museums and individual collections it seems desirable to have their names published. The following pages, dealing with the single genus Drapetis, have been excerpted as the first presentation of the dismembered dissertation. 
the fifty-five North American forms, descriptions of forty-two new species and varieties, and a complete bibliography to the genus and to the 133 described species and varieties at present known from the whole world, including four fossil species. The writer's personal collection contains sixty-seven of the named species and varieties, of which forty-six species are represented by type material. In addition he has studied Coquillett's types at the National Museum and Loew's types at the Museum of Comparative Zoology.

Etymologically the name Drapetis comes from the Greek word Drapetis, meaning a runaway. Since the penult is formed with the short vowel epsilon the accent in English pronunciation falls on the first syllable, $i$. e., Drap-e-tis.

\section{Publications Referring to the Genus Drapetis:}

\section{Drapetis MeIgen}

Meigen, Syst. Bes. iii. 91 (1822).

Curtis, Brit. Ent. viii. 397 (1824).

Macquart, Dipt. Nord Fr. iii. 87 (1S27); Hist. Nat. Dipt. i. 357 (1834).

ZetTERSTEDT, Ins. Lapp. 553 (1838).

Wes'TwOod, Gen. Syn. $132(1840)$.

ZetTERSTEDT, Dipt. Sc. i. 327 (1842).

Bortard, Nouv. Man. iii. 325 (1843).

WALKER, Ins. Brit. Dipt. i. 135 (1851).

Rondani, Dipt. Ital. Prodr. i. 147 (1856).

Bigot, Ann. Soc. Ent. Fr. (3) v. 564 (1857).

SCHINer, F. A. Dipt. i. 95 (1862).

Bigot, Ann. Soc. Ent. Fr. (6) ix. 125 (1889).

CoQuillett, Proc. U. S. Mus. xviii. 390 (1895).

Williston, Manual, 75 (1896).

Becker, Mitth. Zool. Mus. Berl. ii. 43 (1902).

Melander, Tr. Am. Ent. Soc. xxviii. 206 (1902).

Coquillett, Proc. Ent. Soc. Wash. v. 248, 261 (1903).

BezzI, Ann. Mus. Hung. ii. 320, 350 (1904).

Melander, Williston's Man. 223 (1908).

Bezzi, N. Acta. Kais. Akad. xci. 300, 397 (1909).

CoQuillett, Proc. U. S. Mus. xxxvii. 535 (1910).

LunDBECK, Dipt. Dan. iii. 252 (1910).

Melander, Psyche, xvii. 49 (1910).

Wahlgren, Ent. Tidskr. xxxi. 46, 86 (1910).

\section{Crossopalpus Bigot}

Bigot, Ann. Soc. Ent. Fr. (3) v. 557, 563 (1857).

SCUDDER, Nomenclator, 149 (1882) Grossopalpus.

CoQuillett, Proc. Ent. Soc. Wash. v. 248 (1903); Proc. U. S. Mus. xxxvii. $528(1910)$.

\section{Ctenodrapetis BEzzI}

Bezzi, Ann. Mus. Hung. ii. 351, 357 note (1904).

Melander, Psyche, xvii. 49 (1910). 


\section{Elaphropesa MACQUART}

Macolart, I)ipt. Nord Fr. iii. 86 (1827); Hist. Nat. Dipt. i. 359 (1834).

Westwoon, Gen. Syn. $132(1840)$.

Zettersteitr, 1)ipt. Sc. i. 326 (1842).

Bortarl), Nouv. Man. iii. 325 (1843).

Walker, Ins. Brit. Dipt. i. 134 (1851).

Ronibani, Dipt. Ital. Prodr. i. 147 (1856).

Briot, Ann. Soc. Ent. Fr. (3) v. 564 (1857).

SCHINER, F. A. Dipt. i. 94 (1862).

Bigot, Ann. Soc. Ent. Fr. (6) ix. 122 (1889).

Brockre, Mitth. Zool. Mus. Berl. ii. 43 (1902).

Coglaliftr, P'roc. Ent. Soc. Wash. v. 249, 261 (1903).

Brzzi, Ann. Mus. Hung. ii. 321, 346 (1904); v. 567 (1907).

Cogcilles, Proc. U. S. Mus. xxxvii. 537 (1910).

L'NDвн(', I)ipt. Dan. iii. 272 (1910).

Melasiler, Psyche, xvii. 49 (1910).

Wahlikw, Ent. Tidskr. xxxi. 45 (1910).

Bizzzi, Ann. Mus. Hung. x. 478 (1912).

\section{GENERAL MORPHOLOGY.}

Head globular, sometimes slightly longer than high, the occiput more or less hemispherical; eyes large, bare, at most with scattered microscopic hairs, the facets of uniform size, beneath the antennæ the eyes of both sexes nearly touching, leaving the face linear or very narrow, above the eyes the front is V-shaped, always broader than the face, sometimes the front is quite narrow; three small ocelli present. Excision of the eyes at the level of the antennæ very large; cheeks sometimes entirely obliterated, usually about one-eighth the height of the eye, with the oral margin obliquely descending posteriorly. Proboscis thick, rather sharply pointed, perpendicular or directed backward, averaging one-half the height of the head, its labrum with prominent base and as long as the labium; palpi broadly oval, one-jointed, applied to the proboscis, the inside glabrous and shining, the outside pollinose and with more or less evident recumbent pubescence, generally tipped with a longer seta. Antennæ inserted close together a little above the middle of the head, three-jointed, very rarely the basal joint is wanting, the second joint with a circle of small setulæ, the bottom hair of which is sometimes long, the third joint compressed, varying from short oval, not longer than deep and with subterminal arista to lanceolate or conical, nearly twice as long as deep and with terminal arista; the arista usually slender, nearly bare, two-jointed, its basal joint small, its outer joint two or three times as long as the antennæ, rarely the hairy coating is dense and longer so as to give a thickened appearance 
to the arista. Occiput often with a pollinose band on the lower orbits including the cheeks excepting their lower margin, usually with sparse short hairs, typically a pair of ocellar and one of vertical bristles present, rarely two or three pairs of vertical and an additional pair of post-vertical bristles present, sometimes an oral bristle on the back part of the cheeks.

Thorax robust, polished, nearly bare to pubescent, dorsocentral bristles usually limited to a pair of prescutellars, humeral and posthumeral bristles present or absent, notopleural bristles present but variable, scutellum with two or four marginal bristles, the lateral ones always shorter; pleuræ bare, rarely with pollinose streaks following the sutures. Abdomen with eight segments, the first segment laterally inflated, the fourth segment usually large and more heavily chitinized than the others, its sides often pollinose and bearing scimiter-shaped, glistening setulæ, the fifth segment short; pygidium varying from small to large, closed to widely open, asymmetrical, the right side usually with a broad, curved, furcate valve. Legs rather stout, the front femora a little the strongest, usually the anterior femora with a basal flexor hair and with a preapical bristle on the outer side, the hind femora with one to three preapical bristles on the anterior face, hind tibiæ with extensor bristles and more or less produced as an apical tooth-like spur, the anterior tibiæ with a pair of apical bristles; sometimes the legs are devoid of all bristles; pulvilli broad; in those species with broad tibial spur the inside of the hind metatarsi and of the end of the hind tibiæ spongy pubescent.

Wings with anal angle more or less developed, except very rarely the first basal cell shorter than the second which is always fused with the discal cell, five simple longitudinal veins, anal cell completely wanting, at most a short trace of the anal vein present toward the hind margin but the anal cross-vein always lacking, usually the entire margin of the wing uniformly short-ciliate, sometimes the hairs of the first section of the costa are longer, no stigma and no definite color pattern.

The species of Drapetis are included in the following subgenera:

1. Drapetis Meigen, sens. str. Type species, exilis Meigen. Rather small, bristleless, black species, with short antennæ directed somewhat upward, the second joint without a conspicuous seta beneath, the third joint oval, with long, subterminal arista; legs without strong bristles, 
the hind tibix without the terminal spur; notum densely shortpulescent, the hairs appressed, no humeral or discal bristles; wings broad, costa short-pubescent, third rein sometimes curved forward; halteres usually black.

2. Eudrapetis, subgen. nov. Type species, spectabilis Melander. Robust, larger species, more or less bristly and black; antennæ longer, directed obliquely upward, the second joint with a pronounced seta bencath, the third joint ovate to lanceolate, with a long terminal arista; femora with preapical bristles, anterior tibiæ with apical bristles and the hind one's with a more or less evident terminal spur and usually with extensor or apical bristles; humeral, and sometimes discal bristles (e. g., posthumeral, supraalar and anterior dorsocentrals) present; wings broad, costa short-pubescent, third vein straight or recurved; halteres yellow.

3. Elaphropesa Macquart. Type species, ephippiata Fallen. Usually yellow, sometimes black species; antennæ elongate, horizontal, the second joint without seta beneath, the third joint lanceolate, two or more times the length of the first two joints together, the terminal arista relatively short, sometimes no longer than the antennæ; abdomen broad, the middle segment with flattened setulæ; legs slender, the hind tibiae with extensor bristles and with a more or less evident terminal spur; wings narrower, the hairs of the base of the costa longer than elsewhere.

4. Ctenodrapetis Bezzi. Type species, ciliatocosta Bezzi. Body slender, elongate, usually yellow, the abdomen longer than the thorax; antenna elongate, horizontal, the second joint without seta, the third joint lanceolate with relatively coarsely pubescent terminal arista; legs slender, with bristles and a long terminal spur on the hind tibiæ; wings long, narrow, cuneate, the costal margin with long cilia.

\section{Synopsis of the North American Species of Drapetis, s. Lat.}

1. Legs mostly black, femora entirely or mostly black. . . . . . . . . . .

Anterior femora more or less yellowish, in addition to the knees.......23.

2. Hind tibia without evident bristles, tibiæ without apical spurs; halteres black; no dorsocentrals. ....................................

Hind tibia almost always with one or more bristles on the extensor side, tibia with apical spurs; halteres whitish . . . . . . . . . . . . . . 10.

3. Anterior cross-vein before the middle of the discal cell, last section of the fifth vein much shorter than the preceding; third antennal joint short ovate.

Anterior cross-vein beyond the middle of the discal cell, sections of the fifth vein subequal.

4. Wings hyaline, third vein uniformly diverging from the fourth; arista terminal..............................................

W'ings infumated, third and fourth veins parallel toward their end: arista subterminal ..............................

5. Third vein uniformly diverging from the straight fourth; pygidium not cleft; head higher than wide, the eyes nearly touching above the antenna, ocelli minute; mesonotal hairs short.

Third vein becoming subparallel with the fourth toward the end, the fourth vein with a more or less evident downward bend beyond the discal cell; head globular, the eyes distinctly separated above the antenna, the ocelli large; mesonotum pubescent. 
6. Hind femora with two strong processes above; fourth vein ending before the tip of the wing, first vein ending before the middle of the wing, third section of the costa shorter than either the second or the fourth; pygidium large ................................ diversa, $\mathrm{n} . \mathrm{sp}$.

Hind femora unarmed; fourth vein ending beyond the tip of the wing, first vein ending near the middle of the wing, third section of the costa longer than either the second or the fourth; pygidium minute, triangular in outline; front coxæ yellowish................. naica, n. sp.

7. Pygidium small, not deeply cleft, circular in outline; last abdominal

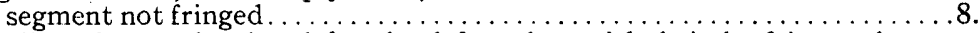

Pygdium large, deeply cleft, the left valve with bristly fringe; last segment of male abdomen fringed with hairs. . . . . . . . . . . . . . .

8. Hind metatarsi yellowish; notal hairs obliquely outstanding; hypopygium transversely depressed, slightly open on the right side; eastern

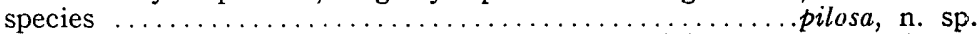

Tarsi black; notal hairs decumbent; hypopygium globular and closed; western species............................micropyga, n.sp.

9. Abdomen and pygidium with fine pale hairs; veins black and thick, the third section of the costa much longer than either the second or the fourth; tarsi and front tibiæ brown.............aliternigra, n. name

Pygidium with many coarse black setulæ; veins slender, the third section of the costa subequal to the second and the fourth; legs entirely black .......................................dividua Melander

10. Hind tibiæ with long, flattened, scale-like hairs along the inner side and with only preapical bristles, the apical spur large and lappet-like; third antennal joint short ovate, the arista subterminal; third and fourth veins converging apically................

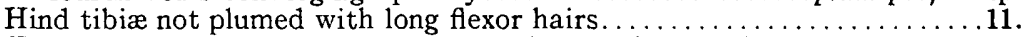

11. Hind tibiæ with six short extensor bristles, the terminal spur strong; arista subdorsal, third antennal joint short ovate.......dorsiseta, n. sp.

At most three extensor bristles on the hind tibia; arista terminal. ......12.

12. Hind tibiæ prolonged on the inside as a strong lappet projecting beyond the insertion of the tarsus, hind metatarsi with strong setulæ beneath, middle tibiæ without extensor bristle; four dorsocentrals.

Hind tibiæ not or scarcely prolonged, certainly not lappet-like, metatarsi

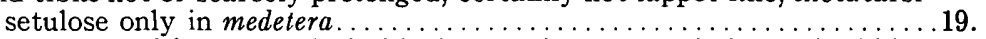

13. Front coxæ and femora entirely black; anterior cross-vein beyond middle of cell; only middle pair of scutellar bristles long . . . . . . . . . . . . . 14 .

Front coxæ somewhat yellowish; anterior cross-vein at or before middle

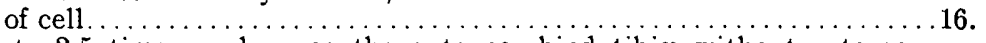

14. Arista 2.5 times as long as the antenna; hind tibiæ without extensor bristles; upper orbits polished; veins coarse and blackish, the first posterior cell narrowed apically..................nitens, $\mathrm{n}$. sp.

Arista 1.5 times as long as the antenna; hind tibia with one or two extensor bristles; occiput pollinose; veins pale, the first posterior cell not markedly narrowed at apex (unipila Loew) ................

15. Hind tibiæ with one bristle, located at the basal third...var. unipila Loew Hind tibiæ with two extensor bristles, one before the middle, the other at the beginning of the apical third of the tibial length...........

var. nitida Melander

16. Scutellum with four long equal bristles; hind tibiæ without extensor bristles; hind metatarsi black, darker than the tibia; palpi black.... quadrisetosa, n. sp.

Scutellum with only the middle pair of bristles long; hind metatarsi rarely contrasting. .

17. Occipital orbits heavily white pruinose; sides of the middle segments of the abdomen white pruinose; posterior cross-vein before the middle of the wing, sections of the fourth vein proportioned 1:1:4, of the fifth vein, $1: 1$.

Orbits not differentiated; sides of the abdomen not pruinose; posterior cross-vein at the middle of the wing, the sections of the fourth vein, $1: 1.2: 2.3$, of the fifth vein, $1: 0.5$, the second, third and fourth sections of the costa, $1.5: 2: 1 \ldots \ldots \ldots \ldots \ldots \ldots \ldots \ldots \ldots \ldots \ldots \ldots \ldots$ inculta Coquillett 
18. Hind thize without extensor bristles; second, third and fourth sections of the costa, 2.5:1.6:1, middle segments of the abdomen with flat glistening setula; base and apex of the front femora, front tibix and base of the front tarsi yellow; palpi yellow................. lata Coquillett

Hind tibia with a strong extensor bristle near the middle, legs uniformly brownish; costal sections, 1.6:1:8:1; palpi blackish...spectabilis Melander

19. Middle tibia with a long extensor bristle at the basal third, hind tibiæ with a bristle above and one below the middle, hind femora with a preapical extensor bristle and with three preapical bristles on the front side; five dorsocentrals; pygidium large; hairs of the mesonotum black of the legs long and blackish.............. medetera Melander

Middle tibia without an extensor bristle, hind femora without extensor hristles, hind metatarsi not setulose; pygidium smaller.

20. Hind tibia without extensor bristles; antenne short, the third joint ovate; veins coarse and brown or black.

Hind tilia with two short extensor bristles located at the middle and near the end; antenna elongate, the third joint lanceolate; veins not coarse and unusually pale.

21. Hind femora of with a strong swelling beyond the middle bulging out the anterior side; vertex broadly polished; basal section of the fifth vein slightly longer than the evanescent outer section; legs brown.

adimera, n. sp.

Hind femora not bearing an ahnormal swelling; vertex subshining, the occiput cinereous, the front and lower orbits white pruinose; sections of the fifth vein subequal; legs mostly black......... parvicornis, $n$. sp.

22. Front femora $\sigma^{7}$ with a bunch of six black setulæ in the middle of the upper side, represented in the of by one or two; no dorsocentrals, dorsum of $\sigma^{7}$ nearly glabrous, of $\%$ with white hairs; one preapical bristle on the front edge of the hind femora............ armata, n. sp.

Front femora not setulose, two preapical bristles on the front edge of the hind femora; five dorsocentrals...................... scissa, n. sp.

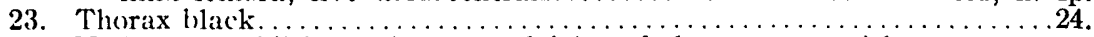

Yellow or reddish species; second joint of the antennæ without a seta

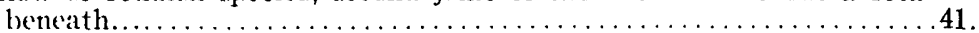

24. Under side of hind femora or armed with a pair of long curved black spinous bristles, legs otherwise bristleless; balteres black; third vein curving away from the fourth; pleuræ shining; palpi and base of antenna yellow............................................

Femora not so armed; species differing from preceding also in two or more other characters.

ird vein curving forward, widely diverging from the fourth; pleuræ opacpue pollinose except the center of the sternopleura; halteres and fringe of calypteres yellow................... divergens Loew

Third and fourth. veins at least subparallel toward their tip; pleuræ shining

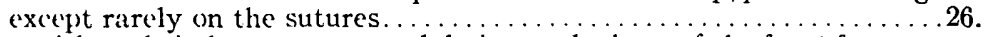

26. Legs without bristle's, at most weak hairs on the base of the front femora beneath and near the apex of the hind ones; no dorsocentrals ......27.

Femora and tibia with bristles; halteres yellow......................

27. Discal cell long, the ultimate section of the fifth vein much shorter than the preceding, posterior cross-vein opposite the end of the first vein, the anterior cross-vein at or before the middle of the discal cell;

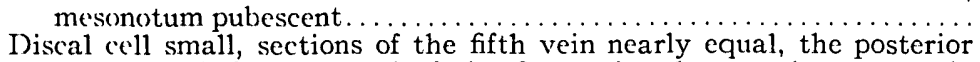
cross-vein before the end of the first vein, the anterior cross-vein beyond the middle of the discal cell, the second section of the costa shorter than the third. ind tibia ciliate along the outer edge; halteres black; veins dark, the second section of the costa equal to the third......latipennis Melander

Tibia not ciliate; halteres yellow; veins brown, the second section of the costa shorter than the third.................... 
29. Antennæ, palpi and proboscis pale yellow; notum not densely pubescent; veins brown, the third vein straight, $\sigma^{7}$ with the pedicel of the second and third veins broadened to a black disk and with a stout flexor bristle near the end of the hind tibia; halteres yellow....ffavicormis. $\mathrm{n}$. sp. Antennæ and mouthparts black; mesonotum densely pubescent; veins black, the third vein sinuous; $\sigma^{7}$ not thus distinguished; halteres

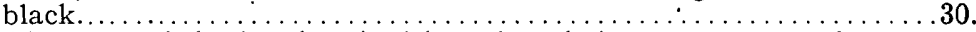

30. Pygidium rounded, closed and without long hairs........... setulosa, n. sp.

Pygidium open, asymmetrical, the right side projecting as a curled, black setulose lamella, the left side of the pygidium clothed with long, black, hair-like bristles....................... trichura, $\mathrm{n} . \mathrm{sp}$.

31. Second antennal joint with a long seta beneath; hind femora with preapical bristles on the front side, hind tibiæ with more or less developed apical spur.

Second antennal joint without a long seta; hind femora without preapical bristles, hind tibiæ with extensor bristles. .

32. Hind tibiz with a strong lappet and with a long extensor bristle at its middle but without subapical bristles; three preapical bristles on the outside of the hind femora, hind metatarsi yellow-setulose beneath; pubescence of the mesonotum long and pale, dorsocentrals present; anterior cross-vein just before the middle of the discal cell; eyes nearly touching above the antennæ. spectabilis Melander

Hind tibiæ without extensor bristle but with subapical ones, hind metatarsi darkened and not setulose; mesonotal pubescence short; eyes

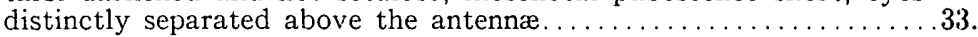

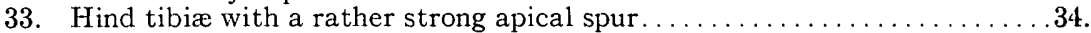

Apex of the hind tibiæ simple; pubescence of dorsum blackish; veins

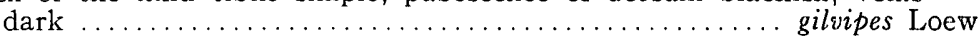

34. Hairs of the thorax and of the calypteres whitish, some weak erect dorsocentrals on the disk of the mesonotum ................. 35 .

Hairs of the thorax and calypteres blackish, no erect dorsocentrals on the disk of the thorax; anterior cross-vein beyond the middle of the discal cell.

35. Anterior cross-vein at the middle of the discal cell; scutellum with four bristles; veins strong; one strong preapical extensor bristle on the hind tibiæ, femora largely blackish..............femoralis Melander

Anterior cross-vein at three-fifths the length of the discal cell, veins weak; scutellum with two bristles; preapical extensor bristle of the hind tibiæ weak, legs mostly luteous

36. Hairs of the thorax fine but dense; face broader above and below and
opaque gray pollinose, front pollinose; legs luteous...... facialis, $\mathrm{n}$. sp. .36 .

Hairs of the thorax sparse; face black, narrower below, the front black; abdomen shining, nearly bare, pygidium very large; hind femora blackish ............................ diversipes, n. sp.

37. Apical spines of the hind tibiæ stout, hind femora usually not blackened; first posterior cell widest before its end..........xanthopoda Williston

Spines at the end of the hind tibia not unusually stout, hind femora dark on the distal half; third and fourth veins parallel...............

(septentrionalis Melander) 38.

38. Face linear, eyes subcontigubus teneath the antennæ; palpi black.

septentrionalis Melander

Face narrow, white pollinose, the eyes distinctly separated; palpi yellow

var. mexicuna, $\mathrm{n}$. var.

39. Hind tibiæ with a single extensor bristle near the middle; front very narrowly $V$-shaped; veins blackish and strong...........inermis, $n$. sp.

Hind tibiæ with two extensor bristles; front narrowly $\mathrm{V}$-shaped; veins slender.

40. Antennæ black, the third joint lanceolate; hairs of the body black and numerous, six acrostichals; sides of the fifth segment of the abdomen with many short scale-like setulæ; tibial spur short......nigricans, n. sp).

Antennæ yellow, the third joint short; hairs of the body pale and very sparse, two acrostichals; tibial spur long.............tenera, n. sp. 
41. Hind tibia without long extensor bristles, but instead seriately bristly, hind metatarsi with an erect comb of seven bristles; halter es blackish; four rows of acrostichals; first posterior cell widest before the end; tilial spur small.

Hind tibia with two or one long extensor bristles, hind metatarsi not pectinate; halteres yellow.

42. Third and fourth veins converging, the first posterior cell widest before its tip; antenna dark; scutellum and metanotum yellow, four acrostichals; tibial spur small...................... inflexa, n. sp.

Third and fourth veins not converging, the first posterior cell widest before its tip; antenne yellow.

43. Mesonotum and pleuræ largely black, the notopleural suture broadly yellow; dorsal hairs long; tibial spur black; one extensor bristle on hind tibia; upper orbits polished................ seminigra, n. sp.

Thorax mostly or wholly yellow.........................

41. Mesonotum with a median brown vitta, upper pleura brown; front linear; tibial spur long..........................

Mesonotum and pleurac not vittate; front narrow, its sides converging below...

45. Hind tibix with a single extensor bristle; posterior half of the mesonotum with a large crescentic black mark..................

Hind tibia with two extensor bristles; posterior part of the mesonotum marked at most with a prescutellar spot

46. Pleura with a large round subalar spot, a rounded prescutellar spot fused with the black scutellum; mesonotal hairs sparse; tibial spur strong but blunt. pleuralis, n. sp.

Pleura unspotted, mesonotum reddish, sometimes with black metanotum, scutellum and prescutellar spot.

47. Tibial sipur blunt; third antennal joint conical, twice as long as broad; abdomen yellow apically; sections of the fourth vein proportioned $1: 3$, of the fifth vein, $2.5: 1 \ldots \ldots \ldots \ldots \ldots \ldots$ rectineura, $n$.

Tibial spur long and sharp; third antennal joint less than twice as long as broad; abdomen often entirely black. dile tibia $\&$ not setulose, of $\sigma^{7}$ at most microscopically setulose; scutellum reddish, mesonotal hairs sparse; length $1.5-2 \mathrm{~mm} . . . . .$.

Middle tibia $\sigma^{?}$ o setulose with black denticles within; scutellum black; genitalia sometimes yellow; mesonotum hairy; sections of the fourth

vein, $1: 2.2 ;$ length $2-3 \mathrm{~mm} \ldots \ldots \ldots \ldots \ldots \ldots \ldots \ldots \ldots \ldots \ldots \ldots \ldots$
49. Sections of the fourth vein proportioned $1: 4 ;$ abdomen black; occiput polished black, without pollen......................... midale segments only; occiput subshining, coated with fine gray

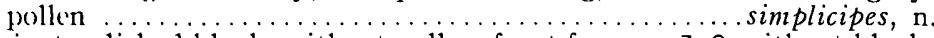

5). ()eciput polished black, without pollen; front femora or $\$$ without black setula below; third antennal joint yellow, arista slender; pygidium without pollen, shining.............................

()eciput pollinose; third antennal joint darker than the basal joints......51.

51. Arista heavily pubescent, appearing half as thick as the third joint; bristles of the hind tibia distant; lower part of the head yellow; second section of the costa longer than the fourth and but little shorter than the third..........................................

Arista not thickly pubescent, less than half as thick as the third antennal

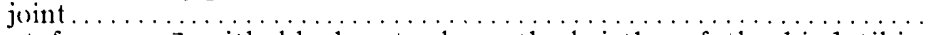

52. Front femora of with black seta beneath, bristles of the hind tibia

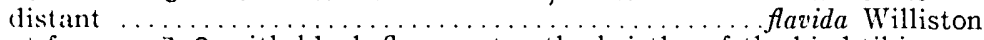

Front femora of $\&$ with black flexor setæ, the bristles of the hind tibixe close together............................... (lata, n. sp.) 53 .

53. I'rescutellar dark spot present; wings three times as long as broad; oriput pollinose to the eyes............... lata, $\mathrm{n}$. sp. and var.

Prescutellar spot wanting; wings less than three times as long as broad. . .54.

54. Spur of the hind tibia forming a long slender curved yellow hook; occiput pollinose to the eyes......................... unar. ungulifera, $\mathrm{n}$. var.

Spur of the hind tibia forming a large broad black lappet; upper occipital orbits shining ......................... nar. nigrocalcarata, $\mathrm{n}$. var. 


\section{Drapetis aliternigra, $\mathrm{sp}$. nov.}

nigra Melander, Tr. Am., Ent. Soc. xxviii. 208, f. 12, 17, 24 (1902).

Length $1.6 \mathrm{~mm}$. Head round; occiput subshining, bottom of the front one-third to one-half as wide as the second joint; face and cheeks linear; palpi black overlaid with brown; second joint of the antennæ without a seta; one pair of diverging postocellar bristles, two or three verticals. Mesonotum closely pubescent, no discal bristles, the lateral ones confined to three or four in front of the wings, lateral scutellar bristles small; pleuræ shining. Legs simple, without bristles, the front knees more or less brownish.

Washington, British Columbia, Texas, South Dakota, Pennsylvania, New York, Massachusetts.

The species is very close to naica, but in that species the third vein has a uniform anterior curve, there are no postocellar bristles, the ocellar and vertical bristles are small and the head is longer than wide, with the front at the.bottom less than onethird as wide as the second joint of the antennæ. In aliternigra the ocellar, postocellar and vertical bristles vary in size.

Drapetis bispina, sp. nov.

$\sigma^{7}$. Length $1.4 \mathrm{~mm}$. Head, thorax and abdomen black, legs including the coxæ entirely yellow. Head spherical; occiput lightly dusted, orbits not differentiated; front and face very narrow, almost linear, the lowermost sides of the dusted face somewhat diverging; antennæ one-third the head-height, the basal joints yellowish, the second joint without seta, the third joint black, triangularly ovate, as long as the basal joints together, the terminal arista one-half longer than the antennæ, short-pubescent; palpi and a pair of apical setæ yellow, proboscis brown. Mesonotal hairs blackish, rather long and dense, obliquely outstanding, only the posterior dorsocentral bristles evident, no humeral, 3 supraalar, 1 intraalar, 4 scutellar bristles, pleuræ mostly polished. Abdomen shining, the hairs rather evident especially the brown ones margining the last tergite and the pale ones of the underside of the hypopygium; hypopygium oblong, larger than the vertical diameter of the abdomen, nearly erect but somewhat twisted. to the right, its left valve with broad rounded end, the penis exserted as a curled filament. Legs relatively stout, covered with yellow hairs which are long but sparse on the underside of the anterior femora, otherwise devoid of bristles except for a pair of contiguous curved black spines located on the inner flexor side of the hind femora at three-fourths the length and extending as far as the knee, inner apical side of the hind tibiæ with a small luteous lappet covering the very base of the metatarsus, no tibial spurs. Halteres black, the roots fuscous; hairs of the calypteres golden. Wings hyaline, veins narrow and light brown, all the veins, diverging, costal sections proportioned $1: 0.6: 1: 0.7$, first vein ending at basal two-fifths of the wing, fourth vein terminating 
conspicuously beyond the tip of the wing, anterior cross-vein located at three-fifths the length of the discal cell, outer sections of the fourth vein proportioned $1: 6$, of the fifth vein, $1: 0.9$, marginal cilia short.

One specimen: Lafayette, Indiana, July 4, 1914. (Melander).

\section{Drapetis diversa, $s p$. nov.}

ơ. $1.3 \mathrm{~mm}$. Black, shining, hairs very short and pale, first four longitudinal veins curving forward, the first vein very short, hind femora with two discoid processes above. Head higher than wide, orbits not pollinose, front very narrow, its sides scarcely converging beneath, face linear, black, cheeks very narrow; palpi and proboscis black; antennæ short, the second joint without a seta beneath, the third joint oval, but slightly longer than wide, the bare arista nearly terminal, one and twothirds times as long as the antenna. Mesonotum with short close pubescence, the marginal bristles small, two scutellar, about eight rows of fourteen acrostichals; pleuræ not pollinose. Abdomen subshining, laterally subopaque, hypopygium large, the lamellæ with coarse brown hairs. Legs devoid of bristles, the hairs pale, the hind femora greatly swollen above and bearing a strong backward-projecting hook on the proximal fourth of its extensor surface, distal to which near the middle is a prominent disk-shaped protuberance. Halteres yellowish. Wings short, broad, hyaline, veins pale brown, first vein ending before the middle of the wing, the marginal cell broad, the second, third and fourth sections of the costa proportioned $1.2: 1: 1$, fourth vein ending slightly before the tip of the wing, the first posterior cell much the widest at its end, anterior cross-vein at two-thirds the length of the second basal cell, outer sections of the fourth vein proportioned $1: \overline{5}$, of the fifth vein equal, costa bare, cilia of the hind margin short.

One specimen: Alamogorda, New Mexico.

\section{Drapetis flavicornis, sp. nov.}

ᄋ. Length $1 \mathrm{~mm}$. Shining black, the appendages yellow. Head ylobular, black, subshining, sides of the front slightly diverging above, face linear, shining black, the narrow cheeks, palpi, palpal seta, proboscis, antenna and arista yellow; antennæ three-jointed, the last joint oval, slightly longer than wide, the arista twice the length of the antenne and microscopically hairy; ocellar and vertical bristles black. Thorax broader than long, its bristles blackish, its hairs moderately sparse, short and brown; pleura polished; abdomen opaque blackish, the middle three segments with two transverse rows of converging setula; ovipositor yellowish. Legs without bristles, the hind tibiæ with a broad blunt sericeous terminal lappet. Halteres yellow; calypteres brown. Wings narrow, clear hyaline, veins brownish along the middle of the wing, at the base and apex pale yellowish, the second, third and fourth costal sections proportioned $1: 1.5: 0.8$, third vein straight, nearly parallel with the fourth, posterior cross-vein somewhat oblique, located before the end of the first vein, sections of the fourth vein pro- 
portioned $1: 0.5: 3.2$, of the fifth vein, $1: 0.7$, marginal cilia as long as the anterior cross-vein.

Type; Le Chorrera, Panama, collected by August Busck, May 12, 1912, for the U.S. National Museum. A male from Jamaica differs only in the following characters which are probably sexual and not specific differences. Pedicel of the second and third veins broadened disc-like and black; hind femora with a strong curved yellow bristle underneath at the outer fourth; mesonotal hairs longer; abdominal setulæ less pronounced.

\section{Drapetis inermis, sp. nov.}

$\sigma^{7}$. Length $1.9 \mathrm{~mm}$. Head black, occiput subshining, front very narrow, its sides converging so as almost to touch, eyes separated below the antennæ by a line, ocellar and vertical bristles moderately long; palpi white and with an apical white hair, proboscis short, reddisin; antennæ horizontal, without seta beneath, the third joint lanceolate, nearly twice as long as broad, its terminal arista less than two times the length of the antenna. Thorax shining black, the hypopleuræ alone pollinose, its pubescence white, uniformly distributed, six rows of about eight acrostichals, lateral scutellar bristles small. Base of abdomen not chitinized, the middle segment laterally with a few flattened setulæ; hypopygium shining black, with few hairs. Legs largely brownish, the anterior femora and coxæ and the base of the hind femora yellowish, middle femora alone with a preapical bristle, hind tibiæ with a single extensor bristle located just above the middle, its apex merely callous, metatarsi not setulose. Halteres yellow, calypteres with six cilia. Wings narrow, nearly hyaline, the veins strong and dark, marginal cilia minute, the second, third and fourth sections of the costa proportioned $1.6: 2.4: 1$, the submarginal cell at the end of the first vein one-half as wide as the marginal, and at the end of the second vein equal in width to the first posterior, third and fourth veins subparallel, the first posterior cell widest beyond the end of the second vein, anterior cross-vein just before the middle of the second basal cell, last two sections of the fourth vein proportioned $1: 2 . \overline{0}$, of the fifth vein, $3: 1$.

One specimen, Alhajuelo, Panama, April 11, 1911, collected by August Busck for the U. S. National Museum.

Drapetis infumata, sp. nov.

o. Length $1.6 \mathrm{~mm}$. Shining black, mesonotum densely blacksetulose, wings infumated. Front broadly V-shaped, at the bottom nearly as wide as the second antennal joint; face narrow, its sides parallel; palpi blackish, with a few dusky hairs; antennæ ascending, the lowermost hair of the second joint setiform, the third joint very short, ovate, the subapical nearly bare arista more than three times as long as the antennæ. No humeral, three or four supraalar, four scutellar, two small prescutellar bristles. Abdomen subshining blackish. Legs blackish, the posterior femora with a small preapical bristle, no tibial 
bristles, or apical spur. Halteres black. Wings oval, the second, third and fourth sections of the costa proportioned $1.3: 1.8: 1$, third and fourth veins subparallel, the first posterior cell a little the widest before its tip, anterior cross-vein before the middle of the discal cell, segments of the fourth vein proportioned $1: 2.3$, of the fifth vein, 1.6 : 1, marginal cilia uniformly short.

Type specimen: Nelson, British Columbia, July 17, 1910. Paratype: Priest Lake, Idaho, August 1, 1915 (Melander). In author's collection.

Drapetis micropyga, sp. nov.

$\sigma^{7}$. Length, 1.j mm. Black, shining, legs simple without bristles, black, the front coxæe and knees brown, antennæe short, halteres black, third and fourth veins nearly parallel. Head round, orbits shining, bottom of the front one-half as wide as the second joint of the antennæ, face linear, cheeks obliterated, proboscis very short, palpi blackish, brown-hairy and without an apical seta; second antennal joint without seta beneath, the third joint short oval, not longer than wide, the subterminal arista slender, twice as long as the antennæ. Pubescence of the mesonotum short and dense, no discal bristles, the lateral bristles confined to three or four in front of the root of the wings, lateral scutellars small; pleure with tomentum in front of the wings and beneath the humeri. Abdomen subshining, nearly bare, hypopygium small, rounded, closed, with uniform short, brown hairs. Wings hyaline, the second, third and fourth sections of the costa proportioned $1: 1.5: 1$, first posterior cell slightly widening toward the tip, fourth vein ending beyond the apex of the wing, its outer two sections proportioned $1: 7$, sections of the fifth rein equal, anterior cross-vein at two-thirds the length of the second basal cell, marginal cilia uniformly short.

Pullman and Almota, Washington: Moscow Mountain, Idaho. A male from Washington, D. C., does not offer any differences.

\section{Drapetis naica, sp. nov.}

$1.2 \mathrm{~mm}$. Black, with simple black legs, third vein curving forward, first vein ending near the middle of the wing, hypopygium small. Head higher than wide, orbits not pollinose, front, face and cheeks very narrow, palpi yellowish, the terminal hair pale, proboscis short, black; antenna short, ascending, the second joint without a seta beneath, the third joint ovate, one-fourth longer than broad, the slender terminal arista one and three-fourths times the antennal length. Thorax with uniform, short, fine, brown hairs, about eight rows of eighteen acrostichal hairs, no humeral, three supraalar, four scutellar, bristles; pleuræe polished; abdomen shining, the sides of the middle segments subopaque and with brown setula; hypopygium small, rather triangular in profile, its valves not open. Front coxæe and knees brownish, posterior femora with a single preapical bristle, spur of the hind tibix long but blunt, metatarsi not setulose. Halteres blackish. Wings hỵaline, veins 
brown and thin, the first four veins curving forward, first vein ending near the middle of the wing, the second, third and fourth sections of the costa proportioned $1: 1.2: 1$, fourth vein ending beyond the tip of the wing, its outer two sections proportioned $1: 6$, anterior cross-vein at two-thirds the length of the second basal cell, costa and hind margin uniformly short-ciliate.

Various places in Washington, Idaho, New Mexico and Texas.

\section{Drapetis pilosa, sp. nov.}

Length $1.25 \mathrm{~mm}$. Black species with halteres and the major portion of the legs black. Head almost spherical, front V-shaped, dusted, ocelli large, face linear; mouthparts black, no long palpal hairs; occiput lightly dusted, orbits not differentiated, cheeks linear; antennæ onethird the head-height, ascending, the second joint not setigerous, the third joint triangularly ovate, scarcely longer than deep, the arista subterminal, three-fourths longer than the antenna. Mesonotum shining, the hairs relatively long, conspicuous and obliquely erect, no humeral, one dorsocentral, one intraalar bristle, only the apical pair of scutellar bristles long; pleuræ polished. Abdomen shining, disc bare, lateral hairs short, stiff and black, last segment without long fringe, fourth segment much longer than any of the others; hypopygium small, transversely depressed, the parts on the right side slightly exposed. Legs entirely bristleless, no tibial lappet or spurs, front tibiæ and all the tarsi yellowish-brown. Hairs of calypteres black. Wings hyaline, veins very thin, brownish, the first vein ending at the middle of the wing, sections of the costa proportioned $1: 0.4: 0.7: 0.3$, of fourth vein, $0.3: 0.2: 10$, third vein sinuate and apically parallel with the fourth, sections of fifth vein subequal.

$q$, thoracic pubescence slightly shorter than in $\sigma^{\top}$.

Type: Lafayette, Indiana, July 4, 1914 (Melander). Four paratypes, Chicago, Illinois, June 28, 1914, on shrubbery in vacant lots near the lake shore (Melander).

\section{Drapetis setulosa, sp. nov.}

Length $1: 3 \mathrm{~mm}$. Shining black, hairs of the mesonotum numerous and black, legs yellowish. Occipital and ocellar bristles stout, lower part of the front one-third as wide as the second antennal joint; palpi blackish, but covered with white hairs; eyes together higher than broad, obliterating the cheeks; antennæ short, ascending, no seta beneath, the third joint short-ovate, with nearly bare subterminal arista measuring three times the antennal length. Mesonotum shining, densely shorthairy; no humeral, five supraalar bunched together, two small prescutellar, two scutellar bristles. Abdomen sub-shining black, hypopygium small, rounded, apically with numerous short yellowish hairs. Legs short, yellowish to brown, the front ones lighter, the hind ones darker, no bristles or terminal spur. Halteres blackish. Wings hyaline, third vein lightly sinuose, parallel with the fourth toward its end, the 
fourth vein with a downward curve in the middle of the wing, then straight, the second, third and fourth sections of the costa proportioned $1.2: 1.5: 1$, submarginal cell as wide as the marginal and the first posterior opposite the ends of the first and second veins respectively, anterior cross-vein near the middle of the second basal cell, outer sections of the fourth vein proportioned $1: 6$, of the fifth vein equal, marginal cilia uniformly short.

Two specimens: Pullman and Almota, Washington, June. A specimen in the U. S. National Museum from South Fork, British Columbia, has the third vein a little closer to the fourth.

\section{Drapetis trichura, sp. nov.}

$\sigma^{7}$. Length $1.4 \mathrm{~mm}$. Black, legs yellowish, hairs black and abundant, the last tergite, apex of hypopygium and of the apical lamella with numerous bristly hairs. Front V-shaped, eyes nearly meeting just above the antenna and on the middle of the face; cheeks narrow; vertical and ocellar bristles short, upper occiput setulose; antennæ ascending, short, black, no seta beneath, the third joint not longer than broad, ovate, with a subterminal arista nearly bare and measuring two and one-half times the antennal length; palpi white and with straggling white hairs, proboscis very short. Mesonotum shining, densely hairy, about ten rows of setulæ between the dorsocentral rows; no humeral, three notopleural, two dorsocentral, four scutellar bristles; abdomen opaque blackish, hypopygium polished jet black. Legs short, simple, without true bristles on the femora or tibiæ, no apical spur on the hind tibix. Halteres blackish. Wings hyaline, the third vein with a strong anterior curve, fourth vein nearly straight but with a slight posterior curve at the middle of the wing, the submarginal cell opposite the end of the first vein two-thirds as wide as the marginal, and at the end of the second vein two-thirds as wide as the first posterior cell, anterior crossvein at two-thirds the length of the second basal cell, the outer two sections of the fourth vein proportioned $1: 10$, of the fifth vein equal, costa and hind margin uniformly short-ciliate.

\section{One specimen: Austin, Texas.}

\section{Eudrapetis armata, sp. nov.}

Length $1 . \$ \mathrm{~mm}$. Black, shining, with black legs, the femora with a single preapical bristle, front femora $\sigma^{7}$ above along the middle with a group of about six spines, reduced in the $q$ to one or two, hind tibiæ with two short extensor bristles located at the middle and about half way to the tip, the apical spur small. Front subshining, at the bottom two-thirds as wide as the second antennal joint, face half as broad as this joint, its sides diverging below, subshining black, cheeks broader behind where they are about one-fifth the eye-height; palpi black but the front surface white pruinose, the apical hair black, proboscis black; antenna elongate, ascending, the second joint with a seta beneath, the third joint lanceolate, about twice as long as broad, its terminal arista rather heavy with close short pubescence, measuring one and two thirds 
times the antennal length. Thorax $\sigma^{7}$ nearly bare, narrowly tomentose before the scutellum and around the root of the wing and conspicuously so below the humeri; pleuræ shining; one strong humeral, four supraalar, one intraalar almost posthumeral in position, two prescutellar, four scutellar, the lateral ones short; in the $q$ the notal hairs are long, fine, abundant and whitish, the lateral bristles are shorter and the subhumeral region is provided with white hairs instead of tomentum. Abdomen shining, nearly bare, in the $\sigma^{\lambda}$ the hairs are blackish and stronger, along the sides of the middle segment slightly flattened, hypopygium short, rather small, its appendages open above. Legs sometimes more or less reddish near the end of the hind tibiæ, the hind metatarsi not setulose, apical spines of the anterior tibiæ long. Halteres white, calypteres with about eight dusky cilia. Wings yellowish hyaline, veins pale brown, first posterior cell rather broad, its veins parallel outwardly, the second, third and fourth sections of the costa proportioned $1.3: 1.3: 1$, anterior cross-vein at three-fourths the length of the second basal cell, outer two sections of the fourth vein proportioned $1: 7$, of the fifth vein equal, marginal cilia uniformly short.

Numerous specimens from Washington, Idaho, Massachusetts and Maine. One specimen from Olga, Washington, has three extensor bristles on the hind tibix.

\section{Eudrapetis discalis, sp. nov.}

$\sigma^{7}$. Length $1.4 \mathrm{~mm}$. Shining black, closely pubescent, legs yellow, posterior cross-vein at the middle of the wing. Occiput with short, brownish hairs and bristles; front V-shaped, at the bottom one-half as wide as the second antennal joint, face and cheeks linear; palpi blackish with a few brown hairs, proboscis short, black; antennæ ascending, the second joint with a seta, the third joint short-ovate, the subterminal arista slender, bare, over three times the antennal length. Hairs of the thorax short, dense, pale, no humeral, three supraalar, four scutellar bristles. Sides of the abdomen subopaque, with white pubescence, disk shining, hypopygium elongate, outwardly with white hairs. Legs slender, the hind femora with short preapical bristles, no tibial bristles or spur. Halteres blackish. Wings hyaline, veins narrow, brownish, . third and fourth veins subparallel, the third lightly sinuose, so that the first posterior cell is widest before its apex, second, third and fourth sections of the costa proportioned $1.4: 1.8: 1$, anterior cross-vein at two-fifths the length of the second basal cell, the outer two sections of the fourth vein proportioned $1: 1.8$, of the fifth vein, $2: 1$, marginal cilia uniformly very short.

Two specimens: Wawawai, Washington, and Palo Alto, California.

\section{Eudrapetis diversipes, sp. nov.}

$\sigma^{7}$. Length $1.9 \mathrm{~mm}$. Black, shining, legs yellowish, the hind femora and metatarsi blackish, hairs of the thorax rather sparse, fine and pale, hypopygium very large. Vertex, front and face grayish black, vertical 
and ocellar bristles large, front beneath nearly as wide as the second. antennal joint, face very narrow, linear beneath, occipital orbits grayish, cheeks broader behind where they are one-tenth the eye-height; palpi brownish, with apical black hair, proboscis brown; antenna black, the second joint with a long seta beneath, third joint broken. Four rows of about nine acrostichals, no discal bristles, two scutellars; pleuræ not pollinose. Abdomen shining, nearly bare, hypopygium with very sparse whitish hairs, the right lamella large, broad and deeply cleft. Legrs luteous, the hind coxæ, femora and metatarsi blackish, pubescence whitish, anterior femora with a single preapical, the hind femora with two preapical bristles, anterior tibix with a pair of apical spines, those of the hind tibie small, its apical spur rather strong and pointed, no extensor bristles on the tibia, hind metatarsi not setulose. Halteres whitish. Wings hyaline, veins pale brown, the fourth vein very slightly undulate, apically parallel with the third vein, the second, third and fourth sections of the costa proportioned 1.(6: $1 .(0: 1$, anterior cross-vein at two-thirds the length of the second basal cell, outer sections of the fourth vein proportioned $1: 6$, of the fifth vein equal, marginal cilia uniformly very short.

One specimen: Santa Cruz Mountains, California, received from Professor R. W. Doane.

\section{Eudrapetis dorsiseta, sp. nov.}

9. Length $2 \mathrm{~mm}$. Shining black, the spur of the hind tibiæ and the matted pubescence of the hind metatarsi brown. Second antennal joint with a long seta beneath, third joint ovate, scarcely longer than broad, the arista arising before the end of the third joint, slender, loosely microscopically hairy, measuring three times the antennal length; face linear, white-pollinose, clypeus shining, cheeks narrow in front, broad behind, lower orbits white-pollinose. Dorsum of the thorax loosely hairy, five hairs in the dorsocentral rows a little longer; halteres yellow. All the femora with a single preapical bristle, front tibiæ with one strong preapical flexor bristle, hind tibia with five erect extensor bristles which in length are equal to the diameter of the tibire but the apical one longer, on the outer side with two short, strong, apical spines and on the inner side with a strongly projecting, broad, blunted spur, hind metatarsi somewhat swollen, not bristly except for one apical setula. Wings narrow, long, hyaline, the veins coarse and black, first vein ending at the middle of the wing, the second, third and fourth sections of the costa proportioned $3.5: 3.7: 1$, third and fourth veins mutually converging at the tip, anterior cross-vein at three-fifths the length of the second basal cell, the outer two sections of the fourth vein proportioned $1: 7$, of the fifth vein $4: 3$, margin with short cilia.

(One specimen: Juan Vinas, Costa Rica, collected by Dr. P. P. Calvert for the Philadelphia Academy of Science. 


\section{Eudrapetis facialis, sp. nov.}

Length $1.5 \mathrm{~mm}$. Broad, black, shining, mesonotum with dense, white hairs and with erect dorsocentrals on the disk, face white-pruinose, legs yellowish. Posterior orbits white-pruinose, front opaque black, as broad as the second antennal joint, face relatively broad, narrowest in the middle, cheeks obliquely descending in back, one-ninth the eyeheight; palpi yellow, proboscis blackish; antennæ black, ascending, the second joint with a seta beneath, the third joint lanceolate, one-half longer than wide, the arista terminal, slender, twice as long as the antennæ. Pleuræ pollinose posteriorly and more or less along the sutures; abdomen shining except along the extreme sides, its hairs sparse, white, hypopygium small, globular. Legs luteous, the hind metatarsi dark, anterior femora with one preapical, hind femora with two, hind tibiæ without extensor bristles but with one pair each of short, stout preapical and apical bristles. Halteres pale yellow; calypteres fringed with six fine white cilia. Wings hyaline, veins pale brown, third and fourth veins converging, the second, third and fourth sections of the costa proportioned $2: 2: 1$, anterior cross-vein at two-thirds the length of the second basal cell, the outer two sections of the fourth vein proportioned $1: 4$, the outer section of the fifth vein shorter than the preceding, margin uniformly short-ciliate.

Two specimens: Okefenokee Swamp, Georgia, June, received through Professor O. A. Johannsen of Cornell University; and Medicine Hat, Alberta, collected by J. R. Malloch and deposited in the U. S. National Museum.

\section{Eudrapetis nitens, sp. nov.}

\% . Length $1.4 \mathrm{~mm}$. Head and body entirely jet black, the legs dark brown, the halteres white. Face linear, front narrowly V-shaped, at the bottom nearly as broad as the width of an antennal joint; lower third of orbits pollinose, occiput, vertex, front and oral margin polished; palpi and proboscis black, the former cinereous pubescent; second antennal joint bisetose below, third joint short oval, the arista slender, microscopically sparsely pubescent, and two and a half times as long as the antenna. Thorax entirely polished, the notal hairs moderate in length and density, the central and distant two scutellar bristles alone long. Hairs of hind tibiæ rather long, four pronounced preapical but no extensor bristles present, the apical lappet strong. Wings lightly infumated, veins strong and blackish, costal sections approximately $1: 0.6: 0.8: 0.3$, third and fourth veins converging at apex, sections of fourth vein as $0.5: 0.4: 1.8$, of fifth vein, $4: 5$.

Type: Panama, March, 1915, received from Dr. A. H. Sturtevant. Paratypes from Havana, Cuba (Sturtevant, and Orizaba, Mexico, (Wm. M. Mann, in Museum of Comparative Zoology) differ in having the legs usually quite black, the posterior occiput slightly pollinose and the mesonotal hairs 
sparse. A male from Aquada, Panama (Sturtevant), has brown legs and wing-veins. The hypopygium is globose but not larger than the abdomen.

\section{Eudrapetis nuda, sp. nov.}

Length $1.6 \mathrm{~mm}$. Shining black, pubescence pale, short and very fine, legs devoid of bristles, yellow, the hind femora largely black. Occipital orbits white-pollinose; eyes separated above the antennæe nearly as much as the width of the second antennal joint, front subshining black; face gray, linear in the middle, cheeks one-tenth the eyeheight, their lower edge horizontal; palpi white and with a terminal white hair, proboscis brown; basal joints of the antennæ yellow, the second joint with a seta beneath, the third joint lanceolate, fuscous, two-thirds longer than broad, with short pubescence, the terminal arista nearly bare, two times the antennal length. Thorax closely covered with short and very fine white hairs, no evident dorso-centrals on the disc, four scutellars, pleura with gray tomentum following the notopleural and the meso-sternopleural sutures. Abdomen subopaque black, its short sparse hairs black, hypopygium of moderate size, shining, with white hairs beneath, the left side with a trifurcate process. Legs simple, without spines or bristles, hind tibiæ not spurred, the last tarsal joint a little darker. Halteres yellowish. Wings hyaline, veins thin, brownish, the third and fourth veins rather strongly convergent, the fourth vein curving forward toward its tip, second vein shorter than usual, the second, third and fourth sections of the costa proportioned $1.3: 4.5: 1$, outer sections of the fourth vein proportioned $1: 6$, of the fifth vein subequal, marginal cilia uniformly short.

Numerous specimens: Kamerun, West Africa, received from Professor Roland Thaxter.

\section{Eudrapetis œdimera, sp. nov.}

$\sigma^{7}$. Length $1 \mathrm{~mm}$. Shining black, with brown legs, black antennæ, blackish palpi, dirty white halteres and strong dark brown veins; hind femora with a pronounced swelling beyond the middle of the anterior face. Second antennal joint with a long inferior seta, third joint short, oval, scarcely longer than wide, its arista long and slender, measuring four times the antennal length, microscopically hairy. Vertex broadly polished, ocellar triangle prominent, occiput slightly dusted, the lower orbits and the lower front only inconspicuously cinereous, face linear, black. Hairs of mesonotum very sparse, brownish, those of the dorsocentral rows long, scutellum somewhat dusted; pleuræ entirely polished; abdomen nearly bare, largely shining, pygidium small, elliptical in outline, sparsely hairy. Anterior tibia with fine apical bristles, hind femora with two apical bristles on the anterior side, hind tibiæ without extensor bristles but with a group of three at the tip, metatarsi not setulose. Wings hyaline, veins broad, the fifth vein evanescent midway between the posterior cross-vein and the margin, first four veins with a slight anterior curvature, the third and fourth veins nearly parallel, 
second, third and fourth sections of the costa proportioned $1: 1.4: 0.6$, anterior cross-vein at three-fourths the length of the discal cell, the posterior cross-vein a little before the end of the first vein, fourth vein ending at the wing-tip, its sections proportioned $3: 1: 9$, basal section of the fifth vein slightly longer than the outer, marginal cilia much longer than the anterior cross-vein, nearly as long as the posterior cross-vein.

One specimen, in the U. S. National Museum. Cordoba, Vera Cruz, Mexico, May 13, 1908, collected by Dr. A. Fenyes.

\section{Eudrapetis parvicornis, sp. nov.}

$\sigma^{7}$, 9 . Length $1.2 \mathrm{~mm}$. Black, shining, the hairs fine, sparse and yellowish. Occiput and front opaque black, eyes separated on the face by a narrow line of pollen, antennal incision deep, front at bottom as broad as the base of an antenna; ocellar and vertical bristles strong; palpi black but white pruinose; antennæ short, black, the second joint with a long seta beneath, the third joint rounded oval, no longer than the second joint, its terminal arista nearly bare. No humeral, two small prescutellar dorsocentral, two scutellar bristles; pleura polished. Pygidium large, ovate, closed, its hairs short, sparse and pale. Legs black, the under side of the anterior femora reddish brown, hind femora with two preapical bristles, hind tibiæ with three apical bristles and with a strong spur, but without extensor bristles. Halteres fuscous, calypteres margined with six cilia. Wings short and broad, lightly infumated, the veins coarse and dark, margin uniformly short-ciliate, second, third and fourth sections of the costa proportioned 1.7:1.S:1, third and fourth veins outwardly subparallel, anterior cross-vein at the outer third of the second basal cell, the last two sections of the fourth vein proportioned $1: 9$, of the fifth vein equal.

Three specimens: Pullman, Washington, March 5, (Melander), and Rock Creek, D. C., March 9 (R. C. Shannon). Paratype in U. S. National Museum.

Eudrapetis pennescens, sp. nov.

o. Length $2.25 \mathrm{~mm}$. Differing from armipes Bezzi in the following respects: Legs blacker, the hind femora with only one pronounced knee bristle, the hind tibiæ with five or six long contiguous hair-like bristles forming a feather-like row along the middle of the inner side and with a strong terminal lappet and stout subapical bristles, the hind metatarsi with blackish and not golden pubescence; wings clear hyaline. Differing from plumipes in being larger and more robust and in having the mesonotum closely white-pubescent, the hind femora with a single knee bristle and the wings hyaline.

Shining black, pubescence white, bristles black, the narrow front, linear face and lower orbits cinereous pruinose; legs almost black, the hind tibiæ dark brown; halteres white; veins black and strong. Palpi blackish, oral margin polished, seta of the second antennal joint strong. 
Second and third sections of the costa subequal, third and fourth veins converging, outer part of the fifth vein abruptly weak, sections of the fourth vein proportioned $3: 2: 9$, of the fifth vein equal.

One specimen: Matucana, Peru, collected by C. T. Brues, July 1, 191:3.

\section{Eudrapetis plumipes, sp. nov.}

ㅇ. Length $1.2 \mathrm{~mm}$. Black, legs blackish, the hind tibiæ with long, feathery, flexor hairs and with a strong terminal lappet, halteres yellow, third and fourth veins convergent. Sides of the pollinose front nearly parallel, face linear, whitish, upper occipital orbits polished, lower orbits pruinose, ocellar bristles large and black; palpi brown, without setax, proboscis black; second antennal joint with a long seta beneath, third joint oval with the arista subterminal, microscopically and closely hairy and more than three times the length of the antennæ. Thorax glistening black, only a narrow pruinose line extending from the middle coxie to the halteres, pubescence long and very sparse, about five short dorsocentrals visible; hairs of the abdomen rather long. Anterior tibia with two terminal bristles, hind femora with two strong preapical bristles, hind tibiæ with three preapical bristles on the exterior side opposite the sharp lappet, hind metatarsi black. Wings somewhat infumated, veins coarse, blackish, basal bristle long, the second, third and fourth sections of the costa proportioned $1: 1.2: 0.4$, first posterior cell distinctly widest at its outer third, sections of the fourth vein proportioned $1: 0.3: 3.2$, of the fifth vein, $1: 0.9$.

Type specimen: Austin, Texas. Paratype, Kushla, Alabama, received from Dr. A. H. Sturtevant. Paratype, Orizaba, Mexico, collected by Wm. M. Mann and deposited in the Museum of Comparative Zoloogy of Harvard University.

\section{Eudrapetis quadrisetosa, sp. nov.}

$\sigma^{7}$. Length $2 \mathrm{~mm}$. Jet black, the halteres whitish. Face linear, pollinose; front $\mathrm{V}$-shaped, nearly shining, at the lowest part nearly as broad as an antennal joint; upper orbits and vertex polished, lowest third of the orbits white pruinose, oral margin broadly shining black; proboscis and palpal ground-color black; second antennal joint with one long bristle beneath, third joint short ovate, the slender subterminal arista nearly three times the antennal length. Notal hairs long, fine, brown and rather abundant, scutellum with an extra pair of long, apical bristles making four long equidistant scutellars in addition to the minor lateral pair. Abdomen with sparse golden hairs; pygidium globose, not swelling the abdomen. Legs sturdy, nearly black, hind tibiie more brown, hind metatarsi darker than the adjacent joints, front tibie with two apical spurs, hind tibire without extensor bristles but with two short but stout preapical spurs, the terminal lappet strong, hind metatarsi scarcely visibly setulose. Wings subhyaline, veins dark but narrow, costal sections proportioned $1: 0.6: 0.8: 0.2$, third and fourth veins slightly convergent, sections of the fourth vein, $0.6: 0.5: 2.1$, of fifth vein equal. 
Type: San Jose, Costa Rica, Central America, March, 1915, received from Dr. A. H. Sturtevanit. Paratypes from same locality and from Orizaba, Mexico (Mann and Skewes), the last in the Museum of Comparative Zoology, Harvard University.

\section{Drapetis scissa, sp. nov.}

Drapetis medetera Melander, in part, Tr. Am. Ent. Soc. xxviii. 208 (1902).

Length $1.7 \mathrm{~mm}$. Shining black, thorax with black hairs and discal dorsocentrals; extensor bristles, apical spines and spur of hind tibia small; antennæ elongate; halteres white; third and fourth veins slightly converging toward tip. Head round, occipital orbits grayish black, bottom of the shining black front two-thirds as wide as the second antennal joint, face black narrowed in the middle where it is nearly onehalf as wide as the second antennal joint, cheeks scarcely deepened behind, one-tenth the eye-height; palpi black, but overlaid with gray, proboscis black; antennæe ascending, second joint with a seta beneath, third joint lanceolate, three-fourths longer than broad, the terminal arista one and three-fourths the antennal length. Pubescence of the thorax fine and rather sparse, six rows of about ten acrostichals, five or six long, slender dorsocentrals, one humeral, one intraalar, two notopleural, three supraalar, four scutellar bristles; a little pollen before the scutellum, pleuræ shining. Abdomen shining, its hairs pale and long, hypopygium of moderate size. Legs black, the pubescence pale, anterior femora with one, hind femora with two preapical bristles, extensor bristles of hind tibiæ located beyond the middle and near the apex, metatarsi not setulose. Halteres white, calypteres with eight pale cilia. Wings broad, hyaline, veins pale brown, the second, third and fourth sections of the costa proportioned $1.4: 2: 1$, anterior cross-vein at three-fourths the length of the second basal cell, outer two sections of the fourth vein proportioned $1: 5$, of the fifth vein equal, first posterior cell widest before its end, marginal cilia uniformly small.

Clayton, Washington; Oxford, Idaho; Hunter's Creek and Rock River, Wyoming, the last from the collection of the University of Kansas.

Eudrapetis septentrionalis, var. mexicana, var. nov.

$\sigma^{7}$. A shining black species with yellowish legs, the hind femora blackened apically, especially along the posterior side, hind metatarsi blackish, palpi yellow. Head higher than long, the lower front, the narrow face and the lower orbits silvery pruinose. Pubescence of the body yellowish, about four longer hairs in the dorsocentral rows. Veins pale brown, posterior cross-vein before the end of the first vein, second to the fourth sections of the costa proportioned $1: 1.2: 0.6$, sections of: the fourth vein, $1: 0.4: 3.3$, of the fifth vein, subequal, marginal cilia a little longer than the anterior cross-vein.

One specimen, in the U. S. National Museum. Collected by F. C. Bishopp, at Tampico, Mexico, December 6. 


\section{Eudrapetis spinipes, sp. nov.}

Length $1 .(\mathrm{i} \mathrm{mm}$. Body polished black, very sparsely hairy, legs luteous, hind tibia with several black spinous bristles toward its apex. Front broadly V-shaped, gray pollinose, at the bottom nearly as wide as the second antennal joint, eyes subcontiguous at the middle of the face, lower occiput white-pruinose, cheeks broad, their greatest diameter one-fifth the eye-height; palpi broad, yellowish, with a single apical hair, proboscis nearly as long as the eye-height, brown; antennæ black, the second joint with a long seta beneath, the third joint oval, slightly longer than broad, the slender subterminal arista loosely microscopically pubescent. The very sparse and short hairs of the thorax black, no dorsocentrals, two scutellars; pleuræ entirely polished. Abdomen shining black, its sparse hairs brown; hypopygium small, closed, beneath with white hairs. Legs including the coxæ and ends of the tarsi entirely yellow, anterior femora with a single preapical, hind femora with two preapical bristles, anterior tibiæ tipped with a pair of long, black spines, hind tibia at two-thirds their length with a long flexor spine, beyond which on the outside are two preapical and two apical spines, all long, on the inside the short broad apical spur is strong, metatarsi not setulose beneath. Halteres yellow. Wings brownish, veins narrow but firm, the third and fourth veins subparallel, the first posterior cell widest before its apex, the second, third and fourth sections of the costa proportioned $1.6: 2.4: 1$, anterior cross-vein at two-thirds the length of the second basal cell, outer sections of the fourth vein proportioned $1: 9$, of the fifth vein subequal, marginal cilia uniformly short.

Numerous specimens: Kamerun, West Africa, received from Professor Roland Thaxter.

\section{Ctenodrapetis aristalis, sp. nov.}

$\sigma^{2}$, 오. Length $1.4 \mathrm{~mm}$. Head glistening black, thorax reddish, abdomen largely or completely black, legs yellow. Front very narrow, eyes contiguous below the antennæ, vertical and ocellar bristles long; basal joints of the antenne short, yellow, without bristles beneath, the third joint elongate, bluntly oval, thickly black-pubescent, the terminal arista twice as long as the antennæe, with dense black pubescence, so as to appear nearly as thick as the antenna itself. Palpi white; proboscis yellow. Thorax polished reddish yellow, the scutellum and metanotum brown, not pubescent, five pale dorsocentrals, the hindmost long, two scutellars. Abdomen with scattered pale hairs, those of the last segment long, apex of the four basal segments sometimes whitish; hypopygium longer than broad, with few hairs and with asymmetrical appendages visible. Legs slender, including the coxæ pale yellow, the anterior tibia and tarsi a little darker, hind tibiæ with only a slight apical swelling and with a single extensor bristle located at the middle, anterior femora with a fine basal hair beneath and all the femora with a preapical bristle on the front side. Halteres white; calypteres white 
and with four long, pale hairs. Wings clear hyaline, veins yellowish, the outer half of the fourth and fifth veins darkest, costa provided with long, isolated hairs only on the basal half; in outline the wings are narrow, especially on the proximal portion, the anal angle almost entirely reduced; third section of the costa slightly longer than the second, and two and one-half times as long as the fourth section, third vein lightly sinuose, diverging from the fourth and with an anterior curve at its very apex, the submarginal cell beyond the second vein as wide as the first posterior, the anterior cross-vein short, located at three-fifths the length of the second basal cell, last two sections of the fourth vein proportioned $1: 5$, of the fifth vein, $5: 3$; marginal hairs long.

Thirty-five specimens: Manila, Philippine Islands, Robert Brown, collector, from the U. S. National Museum.

Ctenodrapetis cuneipennis, sp. nov.

․ Length $1.5 \mathrm{~mm}$. Head globular, occiput glistening black., nearly bare, the vertical and ocellar bristles rather short, front narrow, its sides parallel, eyes contiguous below the antennæ; antennæ yellowish, without bristles beneath, the third joint slightly darker, bluntly lanceolate and densely short-pubescent, two and one-half times as long as wide, the terminal arista one and one-half times the antennal length, bushy with dense black pubescence so as to appear nearly as thick as the antenna itself. Palpi white; proboscis yellow. Thorax flavous, including the scutellum, metanotum and pleuræ, but with a brown spot above the root of each wing. The four basal segments of the abdomen whitish with very narrow, brown sclerites, the tergite of the fifth segment large, corneous and brown. Halteres white; calypteres with two pale hairs. Legs slender, pale yellow, the hind tibiæ with small apical spur and with two extensor bristles near the middle. Wings slender, hyaline, the veins pale, the anal angle very greatly reduced, the third section of the costa twice as long as either the second or the fourth, the third vein lightly sinuous and diverging from the fourth so that the submarginal cell is not nearly so broad as the first posterior, anterior cross-vein short, located before the middle of the second basal cell, the last two sections of the fourth vein proportioned about $1: 3$, of the fifth vein, $5: 3$, marginal hairs long.

One specimen: Manila, Philippine Islands, Robert Brown, collector; in the U. S. National Museum.

\section{Elaphropeza calva, sp. nov.}

$1.5 \mathrm{~mm}$. long. Shining yellow species with yellow legs, the occiput polished black, the middle segment of the abdomen blackish; middle tibiæ denticulate within, spur of the hind tibiæ short, posterior crossvein at the middle of the wing. Antennæ entirely yellow, the third joint ovate, one-half longer than broad, the arista microscopically pubescent and three times as long as the antennæ; front narrow, shining, face linear; occiput with a little pollen near the neck, the 
yellow hairs and bristles prominent; mouthparts yellow. Hairs of the thorax long but sparse, scutellum and metanotum reddish brown; base and apex of the abdomen testaceous yellow, the pygidial valves rather large, lateral hairs of the middle segment scale-like. Legs hairy and moderately stout, the middle femora a little the strongest, front femora not setose, the distance between the bristles of the hind tibiæ less than one-third the length of the tibix, the terminal spur small and yellow. Wings narrow, more than three times as long as broad, veins yellow, second, third and fourth sections of the costa proportioned $1: 1.8: 0.8$, sections of the fourth vein, $1: 1: 2.3$, of the fifth vein, $1: 0.4$.

Six specimens: Corazal, Panama, and Motzorongo, Vera Cruz. Type in the U. S. National Museum.

Elaphropeza comata, sp. nov.

or. Length $1.7 .5 \mathrm{~mm}$. Head black, thorax entirely reddish, middle segments of the abdomen blackish, hairs and bristles pale, hind legs loosely pectinate. Front very narrow, almost linear; antennæ fuscous, without seta beneath, the third joint lanceolate, two times as long as broad, the arista twice as long as the antenna, with short pubescence; palpi and proboscis yellow. Thorax rather hairy, four rows of about seven acrostichals, two scutellar bristles. Middle segment of the abdomen with many flattened setulæ, last tergite with long hairs, hypopygrium elongate, with numerous hairs at apex and below. Legs yellow, the last tarsal joint dark, middle femora alone with preapical bristle, hind tibia without long extensor bristles, but instead with a series of about ten shorter, regularly placed, erect bristles, similarly the hind metatarsi provided with seven erect extensor bristles, spur of hind tibix very small and blunt. Halteres dusky, calypteres with eight dusky cilia. Wings rather broad, clear hyaline, the veins brown, the second, third and fourth sections of the costa proportioned $1.6: 2.5: 1$, the third and fourth veins nearly straight, very slightly converging apically so that the widest part of the first posterior cell is just beyond the termination of the second vein, anterior cross-vein before the middle of the second basal cell, last two sections of the fourth vein proportioned $1: 2$, of the fifth vein, $3: 1$.

One specimen: Trinidad Island, West. Indies, collected by August Busck, for the U. S. National Museum.

\section{Elaphropeza inflexa, sp. nov.}

Lengrth $1.4 \mathrm{~mm}$. Occiput black, front narrowly $\mathrm{V}$-shaped, at the bottom one-third as wide as the second antennal joint; antennæ rather short, blackish, the second joint without seta, the third joint broadly lanceolate, one-half longer than broad, the arista short-pubescent and one and three-fourths times as long as the antennæ; palpi short, whitish, proboscis red. Thorax, including the scutellum and metanotum luteous, unmarked, the hairs noticeable but scattered, four rows of about six acrostichals. Abdomen blackish, the sides of the middle segment with many minute scale-like setula, last tergite fringed but the elongate 
hypopygium nearly bare. Legs yellow, the front femora with a short preapical bristle, that of the middle femora stronger, hind tibia with two extensor bristles trisecting its length and with a short blunt terminal spur. Halteres dirty yellow, calypteres fringed with five cilia. Wings clear hyaline, the second, third and fourth sections of the costa proportioned $1.5: 2.5: 1$, third vein with pronounced anterior curve, the fourth vein nearly straight, submarginal cell at the end of the first vein nearly as wide as the marginal cell, and beyond the end of the second vein narrower than the first posterior cell, which latter is widest at three-fourths its length, the last two sections of the fourth vein proportioned $1: 2.7$, of the fifth vein, $2: 1$, marginal cilia short.

Four specimens, Canal Zone, Panama, collected by August Busck for the U. S. National Museum. The species is near formose Bezzi, but has a longer arista.

\section{Elaphropeza læta, sp. nov.}

$\sigma^{7}$, ㅇ. Length $1.7 \mathrm{~mm}$. Shining yellow, with yellow antennæ, mouthparts and legs, the scutellum, metanotum, abdomen and a prescutellar spot blackish; middle tibiæ denticulate within, front femora not black setose. Head black except the posterior oral margin, occiput cinereous-pollinose, front very narrow, almost linear, shining, eyes of male contiguous below the antennæ, obliterating the face, in the female the eyes are subcontiguous; vertical bristles brown, palpal setze yellow; third antennal joint ovate, one-half longer than broad, the arista closely but microscopically pubescent, brown, two and a half times as long as the antennæ. Hairs of the thorax moderately abundant and long, bristles yellow. Middle segment of the abdomen darkest, with lateral flattened setulæ, pygidium sericeous. Legs rather slender, front femora sparsely ciliate below, middle femora with strong preapical bristle, not denticulate below, the antero-flexor edge of the hind femora with stiff yellow setæ, six outstanding extensor hairs toward the base of the hind femora, hind tibiæ with a rather strong black terminal lappet, the two extensor bristles separated by less than one-third the length of the tibia. Wings three times as long as broad, veins strong and brown, second, third and fourth sections of the costa proportioned $1: 1.3: 0.8$, third and fourth veins straight, slightly diverging, sections of the fourth vein proportioned $0.9: 1: 2.2$, of the fifth vein. $1: 0.4$.

Five specimens: Alhajuelo, Panama; August Busck, collector. Type in U. S. National Museum.

Var. ungulifera, new. A male specimen from Corozal, Panama, differs in having the spur of the hind tibia long, very slender and curved, measuring as long as the third tarsal joint. The scutellum is reddish and the prescutellar spot is lacking. The veins are light yellow and not coarse.

Var. nigrocalcarata, new. A male specimen from Alhajuelo, Panama, differs in having the spur of the hind tibia very large and broad and black, so it contrasts markedly with the remainder of the legs. The 
prescutellar spot is lacking but the scutellum is blackish like the metanotum and abdomen. The upper occipital orbits are polished and the veins are only moderately brown. The wings of both variations are less than three times as long as broad. Possibly these specimens represent distinct species. They are deposited in the U. S. National Museum.

Elaphropeza luteicollis, sp. nov.

Length $1.5 \mathrm{~mm}$. Slender, the head and abdomen black, thorax reddish, legs yellow, apex of the tibix black, hairs and bristles yellow. Front narrow, its sides slightly converging below, at the bottom onefourth as wide as the second antennal joint, eyes separated by a line beneath the antennæ; palpi white, proboscis short, brown; antennæ horizontal, yellow, no seta beneath, the third joint lanceolate, one-half longer than wide, the arista two and six-tenths times as long as the antennæ, its pubescence close and short. Thorax reddish yellow, the metanotum and rarely the scutellum brown, hairs very sparse, two rows of two acrostichals, only four hairs in the dorsocentral rows. Sides of middle abdominal segment with flattened setulæ; hypopygium black, nearly bare. Hind tibiæ with two extensor bristles trisecting its length, the terminal spur long and sharp. Halteres yellow. Wings clear hyaline, veins narrow, light brown, marginal cell moderately long, the second, third and fourth sections of the costa proportioned $1: 1.8: 1$, the third and fourth veins straight, uniformly and slightly diverging, the first posterior cell widest at the apex, the anterior cross-vein at the middle of the second basal cell, last two sections of the fourth vein proportioned $1: 3$, of the fifth vein, $1.8: 1$.

Forty specimens, collected by August Busck for the U. S. National Museum in various places in the Canal Zone of Panama.

Elaphropeza nigricans sp. nov.

$\sigma^{7}$. Length $1.7 \mathrm{~mm}$. Near tenera but with longer antennæ, shorter arista and more hairy body. Front narrowly V-shaped, at the bottom one-third as wide as the second antennal joint; ocellar and vertical bristles long and blackish; antennæ black, the second joint without long seta, the third joint lanceolate, twice as long as wide, the terminal arista scarcely longer than the antennæ, short-pubescent; eyes nearly contiguous below the antennæ; palpi white, and with a few white hairs; proboscis short and brown. Thorax polished black, but uniformly covered with long, black hairs, forming four rows of acrostichals with about eight hairs to each row, prescutellar and scutellar pairs of bristles long and black. Abdomen shining black, the sides of the middle segment with many scale-like setulæ; hypopygium minute. Legs yellow, the outer third of hind femora brown, hind tibiæ with two extensor bristles and with a very short and blunt apical spur. Halteres whitish; calypteres with five dusky hairs. Wings clear hyaline, veins narrow but dark, the second, third and fourth sections of the costa proportioned 
$1.5: 2: 1$, the third and fourth veins straight, very slightly divergent, the last two sections of the fourth vein proportioned $1: 2.7$, of the fifth vein, $2.5: 1$, hairs of hind margin short.

One specimen: Corazal, Canal Zone, Panama, March. Collected by August Busck for the U. S. National Museum.

\section{Elaphropeza pleuralis, sp. nov.}

Length $2 \mathrm{~mm}$. Robust, yellow species marked with black, hairs and bristles yellow. Occiput polished black, the occipital bristles longer than the ocellar; front very narrow, its sides converging below, at the bottom one-fourth as wide as the second antennal joint, eyes almost contiguous below the antennæ; palpi pale yellow and with a few yellow hairs, proboscis luteous; antennæ horizontal, pale yellow, the second joint with a circle of setulæ but without seta beneath, third joint shortlanceolate, one and one-half times as long as wide, the terminal arista pubescent, two and one-half times as long as the antenna. Thorax luteous, marked with a black, prescutellar spot, which is round in front and includes the scutellum and metanotum behind, a round prealar spot on the mesopleuræ, encroaching on the sternopleura; mesonotal hairs sparse, two rows of four acrostichals, a pair each of prescutellar and scutellar bristles. Abdomen yellow, not chitinized except the black middle segment and the narrow one following, sides of these segments with many flattened black setulæ; last tergite fringed with hairs, hypopygium small, elongate, rather hairy. Legs yellow, the last tarsal joint black, only the middle femora with preapical bristle, spur of the hind tibiæ long, blunt, brown, two extensor bristles on the hind tibiæ, one at the middle and one half-way to the knee. Halteres whitish, calypteres dark, with seven brown cilia. Wings clear hyaline, veins thin and brown, the second, third and fourth sections of the costa proportioned $1.5: 2.5: 1$, the third and fourth veins parallel, the submarginal cell at the end of the first vein one-half as wide as the marginal and at the end of the second vein equal to the first posterior, last two segments of the fourth vein proportioned $1: 2.7$, of the fifth vein, $2.5: 1$, marginal cilia short.

Four specimens: Alhajuelo, Panama, and Orizaba, Vera Cruz; from the U. S. National Museum.

\section{Elaphropeza plumea, sp. nov.}

o. Length $2.2 \mathrm{~mm}$. Robust shining yellow species with black occiput and heavily pubescent arista, discal cell large. Front very narrow, almost linear, shining black, face linear and black., occiput finely gray pollinose, cheeks and proboscis yellow, palpi large and white, epistome white pollinose; vertical bristles black; antennæ yellow, the second joint with uniform setulæ, the third joint ovate, one-half longer than broad, the blackish arista including its dense hairs appearing as thick as one-half the diameter of the third joint. Thoracic hairs moderately dense, the bristles yellowish; tip of the scutellum, center of the metanotum and a prescutellar spot brown. Middle segment of the 
abdomen brown and with flattened lateral setulæ. Legs slender, flexor hairs of the front femora long and yellow, middle tibiæ armed within with two rows of minute hook-like black setulæ, the apex angulate and black, hind tibiæ with two extensor bristles located before the basal third and beyond the apical third, the apical lappet sharp and rather strong. Halteres yellow. Wings narrow, more than three times as long as wide, veins yellow, second, third and fourth sections of the costa proportioned $1: 1.3: 0.6$, third and fourth veins nearly straight and parallel, sections of the fourth vein proportioned $1: 1: 2.2$, of the fifth vein, $2.5: 1$.

One specimen: Orizaba, Mexico (H. H. Smith); in author's collection.

Elaphropeza rectineura, sp. nov.

Length 1.6 $\mathrm{mm}$. Robust, yellow species, with pale hairs and bristles, last tarsal joint blackish. Head black, front narrow, the sides slightly converging below, at the bottom one-third as wide as the second antennal joint, ocellar bristles long, eyes contiguous beneath the antennæ; palpi white, proboscis short, yellow; antennæ yellow, the second joint without seta, the third joint broadly lanceolate, scarcely twice as long as broad. Thorax loosely hairy, two rows of six acrostichals, scutellum yellow, with lateral bristle one-fourth as long as the apical pair, metathorax yellow. Abdomen brownish yellow in the middle segments, where laterally there are many minute flattened setula. Middle femora alone with preapical setulæ, hind tibiæ with two long extensor bristles trisecting its length, the apical spur short and blunt. Halteres yellow, calypteres with five cilia. Wings clear hyaline, rather broad and rounded, marginal cilia short, the second, third and fourth sections of the costa proportioned $1: 2: 1$, the third and fourth veins nearly straight, uniformly but slightly diverging, the first posterior cell widest at its apex, anterior cross-vein before the middle of the second basal cell, the outer two sections of the fourth vein proportioned $1: 2.7$, of the fifth vein, $2: 1$.

Two specimens: Tabogal and Corazal, Panama, collected by August Busck for the U. S. National Museum.

\section{Elaphropeza seminigra, sp. nov.}

$\sigma^{7}$. Length 2.) $\mathrm{mm}$. Partly testaceous yellow and partly black. (cciput black, the upper orbits largely shining, the remainder pollinose, ocellar bristles brown, reaching to the antennx, vertical bristles long and black; front very narrowly triangular; antennæ yellow, the third joint but slightly longer than deep, its blackish arista three times the length of the antenna proper, closely and evidently pubescent; palpi yellow, proboscis tipped with black. Thorax shining, the mesonotum broadly yellow about the shoulders, medially black, the dark coloring extending from side to side at the wings, bristles and hairs long and yellow, four rows of scattered acrostichals; scutellum and metanotum black, the apical pair of scutellar bristles approximate, long and cruciate; 
pleuræ irregularly marked with black and reddish yellow, the mesopleuræ blackened except toward the coxæ. Abdomen yellowish, the middle and apical segments black, scales of the middle segment prominent on a gray velvety setting, abdominal hairs yellow. Legs yellow, the tarsi becoming dusky at the apex, front legs devoid of setulæ, middle femora and tibiæ with close-set rows of black setulæ, anterior femora with a long basal, yellow bristle underneath, hind tibia with a single black extensor bristle at two-fifths its length, the apical spur blackened, curved and pointed. Halteres pale yellow. Wings yellowish hyaline, their roots yellow, veins brown, costal sections proportioned 4:1.5: $2.5: 1$, third and fourth veins parallel toward the end, anterior crossvein at middle of the second basal cell, posterior cross-vein at the middle of the wing, sections of the fifth vein $2: 1$, costal hairs conspicuous.

Two specimens: San Jose, Costa Rica, March, 1915, received from Dr. A. H. Sturtevant.

\section{Elaphropeza simplicipes, sp. nov.}

Length $1.5 \mathrm{~mm}$. Yellow, head cinereous black, scutellum, metanotum, middle segment of the abdomen and a vague prescutellar spot blackish, antennæ, mouthparts and legs yellow, middle tibiæ of the male with microscopic denticles within, of the female without denticles. Front narrow, shining, its sides nearly parallel, face linear, whitepollinose, vertical bristles brownish, third antennal joint conical, onehalf longer than broad, the arista microscopically pubescent, about two and one-third times the antennal length. Mesonotum with sparse hairs, its bristles yellow; lateral setulæ of the middle segment of the abdomen flattened; upper valve of the brownish pygidium rounded and sericeous, the apical fringes short. Legs rather slender and short, front femora without black setæ, the two extensor bristles of the hind tibiæ close together, the apical spur moderate, yellowish, velvety and rather acute, last tarsal joint not dark. Wings less than three times as long as broad, veins yellow and thin, second, third and fourth sections of the costa proportioned $1: 1.7: 1$, third and fourth veins straight and slightly diverging, sections of the fourth vein proportioned $1: 1: 2.2$, of the fifth vein, $1: 0.4$.

Montego Bay and Balaklava, Jamaica. Type in the Boston Society of Natural History.

A male specimen from Victoria, Texas, in the U. S. National Museum, is associated here. It is larger, measuring two millimeters, has the outer antennal joint dark, the metanotum reddish and the last tarsal joint dusky. Although phyletically it probably represents a distinct species the visible differences are too slight to utilize.

Elaphropeza tenera, sp. nov.

Length $1.5 \mathrm{~mm}$. Polished black of a brownish tinge, hairs very sparse and pale. Front narrow, the sides nearly parallel, at the bottom less than one-half the width of the second antennal joint; ocelli minute, 
the ocellar bristles long; eyes nearly touching below the antennæ; palpi broad, white, with a couple of white bristles, proboscis yellow; antenne short, yellow, the last joint short-lanceolate, one and one-half times as long as wide, the arista three times the antennal length, microscopically pubescent. Hairs of middle abdominal segment strong, but not scale-like in the Trinidad specimen; hypopygium small. Legs including the coxe pale yellow, slender, the front trochanters with a black dot, apex of hind tibia blackish in the Trinidad specimen, middle femora alone with preapical bristle, hind tibiæ with two extensor bristles, the outer one small, the apical spur long and thumb-like. Halteres whitish; calypteres with four pale cilia. Wings clear hyaline, veins pale, the third section of the costa one and one-half times either the second or fourth section, the third and fourth veins straight, slightly diverging, the last two sections of the fourth vein proportioned $1: 4$, of the fifth vein, 2: 1 , wing margin ciliate.

Two specimens. Porto Bello, Panama, March 13, 1911, in the collection of the U.S. National Museum, and Montserrat, Trinidad Island, June 29, both collected by August Busck.

\section{Elaphropeza uniseta, sp. nov.}

․ Occiput black, lightly pollinose, a spot on each side of the vertex shining, ocellar and vertical bristles short and black; front very narrow, linear, eyes subcontiguous beneath the antennæ; palpi and proboscis yellow, the palpi with scattered blackish hairs; antennæ horizontal, brown, the third joint triangular, twice as long as deep, the blackish arista slender, microscopically and closely pubescent, twice as long as the antennæ. Thorax shining reddish yellow, mesonotum with a median vitta abbreviated behind, and with a spot above the notopleural suture dark brown, center of the scutellum and the inflated sides of the first abdominal segment also brown; abdomen weakly chitinized except the middle segment whose sides are thickly studded with black scale-like setula; hairs of the thorax fine, dark, confined to the anterior region, comprising a few posthumeral and four definite rows of acrostichals with about five hairs to each row; presutural dorsocentral long, scutellum with two long cruciate bristles. Legs including the coxæ yellow, a little dusky distally, anterior femora with basal hair below, middle femora - with a strong preapical bristle, hind tibiæ with a single strong extensor bristle located below the middle and with a broad blunt apical spur. Knob of halteres blackish; calypteres small but with a fan-like fringe of dark cilia. Wings hyaline, veins yellow, first vein ending beyond the middle, third section of the costa about three times either the second or the fourth section, marginal cell at the end of the first vein nearly twice as wide as the submarginal, the latter at the end of the second vein as wide as the first posterior cell, third vein lightly sinuous, converging with the fourth on its outer portion, anterior cross-vein before the middle of the second basal cell, the outer two sections of the fourth vein proportioned $1: 2$, of the fifth vein, $3: 1$, costa with a basal hair, but not long ciliate, hairs of the posterior margin of the wings very short.

One specimen: Manila, Philippine Islands, Robert Brown, collector, in the U. S. National Museum. 


\section{Elaphropeza upsilon, sp. nov.}

$0^{x}$. Length $1.5 \mathrm{~mm}$. Largely yellow with yellow legs and antennæ, the posterior part of the mesonotum marked with a broad U-shaped mark, hind tibiæ with a single extensor bristle located just before its middle, middle tibiæ microscopically denticulate along the flexor side. Head black, occiput pollinose up to the eyes, face linear, white-pollinose; mouthparts yellow; third antennal joint short-ovate, the arista less than three times as long as the antennæ and microscopically pubescent; vertical and ocellar bristles yellow. Hairs of the mesonotum rather sparse and long, bristles yellow; the black mark fills the posterior half of the mesonotum except in the middle and except the postalar callus; scutellum, metanotum and middle segment of the abdomen black, the middle segment of the abdomen with scale-like setulæ along the sides; pygidium brown, glabrous except the marginal fringe. Hind tibiæ with a moderate, acute, yellow, velvety, terminal lappet. Veins brown, second and third sections of the costa nearly equal, third and fourth veins nearly parallel, sections of the fourth vein proportioned $1: 1: 2.2$, of the fifth vein. $1: 0.4$.

\section{Jamaica (Brues). In author's collection.}

\section{Elaphropeza vittata, sp. nov.}

\%. Length $1.8 \mathrm{~mm}$. Robust, yellow marked with black. Occiput black, lightly pollinose, its bristles and the ocellars pronounced; front linear, its sides parallel, eyes separated below the antennæ by a dense row of microscopic white hairs; palpi white and with white hairs, proboscis yellow; antennæ destroyed. Thorax polished reddish yellow, marked with a black vitta which is broadest behind and there includes the scutellum and metanotum and meets a black pleural vitta. The median vitta is not sharply bounded, the pleural vittæ fill the meso- and meta-pleuræ. The thoracic hairs are rather long and isolated, two rows of six acrostichal hairs, a pair each of prescutellar and scutellar bristles. Abdomen pale yellow, only the middle segment fully chitinized, the basal segments with only small lateral sclerites, the sides of the middle segment with many glistening scale-like setulæ. Legs yellow, the anterior tibiæ and all of the tarsi a little brownish, anterior femora with a moderate preapical bristle, hind tibiæ with two strong extensor bristles trisecting their length, their terminal spur long and sharpened, pale brown. Halteres white; calypteres ciliate with five brown hairs. Wings clear hyaline, veins yellow, third section of the costa nearly twice as long as the second or fourth, third and fourth veins parallel at the end, anterior cross-vein before the middle of the second basal cell, outer sections of the fourth vein proportioned $1: 2.5$, of the fifth vein, $3: 1$, hind margin with short cilia.

Type specimen from the U. S. National Museum, labeled "on pineapple," Lemon City, Florida, April 12, 1899. A defective specimen from Havana, Cuba, (Dr. A. H. Sturtevant), is apparently the same, differing in that the pleural blackening is less pronounced. 


\section{Bibliographic List of the Species of Drapetis.}

A. Subgenus Drapetis Meigen, sens. str.

aliternigra, new name......................... North America nigra Mel,axder, not Meiges, Tr. Am. Ent. Soc. xxviii. 208, f. 12, 17, 24 (1902). L'Nink(k, I)ipt. Dan. iii. 257, note (1910).

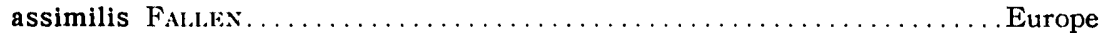

Faldex, I)ipt. Suec. Emp. \&, 4, 34, (1815) Tachydromia; Walker, Ins. Brit. 136, (1851); Schiner, F. A. i. 95 (1862); Lundbeck, Dipt. Dan. iii. 256. f. 11 i (1910); WAhlores, Ent. Tidskr. xxxi. 87 (1910). Frey, Acta Soc. Fenn. xxxvii. (3) 71 f. 19 (1913).

affinis LokW, N. Beitr. vi. 41. (1859).

arculata Lofw, N. Beitr. vi. 40, (1859); SchINER, F. A. i. 96 (1862); WAHLGREN, Ent. Ti(lskr. xxxi. 87 (1910); Kuntze, I)eut. Ent. Zts. 548 (1913).

minima MeIcik, not ZetTerstedt, B. S. vii. 100 (1838).

nigra Mrisfes, S. B. vi. 344 (1830); Curtis, Brit. Ent. viii. 397 (1832); MaCQ'ART, Suit. a Buff. i. 358 (1834); WALKER, List, iii. 511 (1849) occ. in Canada; Walker, Ins. Brit. i. 136 (1851).

pygmca Roser, Wurttemb. Correspb). i. 54 (1840).

bispina, new species. . . . . . . . . . . . . . . . . . . . . . . Indiana

brevior BRLETTI . . . . . . . . . . . . . . . . . . . . . . . . . . . India BRtNetTr, Rec. Ind. Mus. ix. 37 (1913).

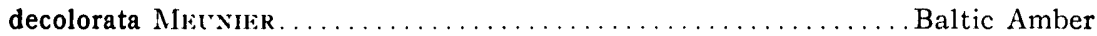
Meriere, Ann. Sci. Nat. Zool. vii. 95 (1908).

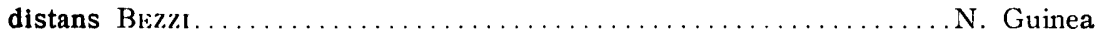
Bezz, Wien. Ent. Ztg. xxiii. 144 (1904); Ann. Mus. Hung. x. 480 (1912). divergens BEz\%, not LoEw, Ann. Mus. Nat. Hung. ii. 353 (1904).

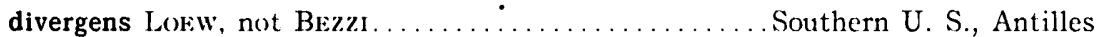
LolEw, not Bezzi, Berl. Ent. Zeitschr. xvi. 90, Cent. x. 62 (1872); Melaxder, Tr. Am. Ent. Soc. xxviii. 210. f. 15 (1902); BezzI, N. Act. Kais. Akad. xci. 397 (1909).

minuta Wil.tiston, Tr. Ent. Soc. Lond. iii. 442. f. 168 (1896); Melander, Tr. Am. Ent. Soc. xxviii. 210 (1902).

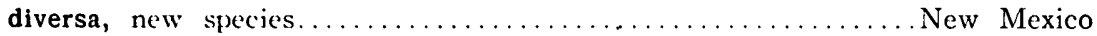

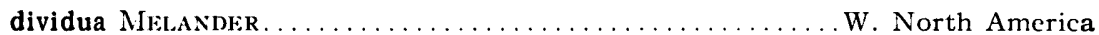
Mel.ANDER, Trans. Am. Ent. Soc. xxviii. 208, pl. 5, f. 16, 18, 23 (1902).

nigripes Melander, Tr. Am. Ent. Soc. xxviii. 339 (1902) Stilpon.

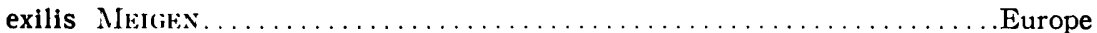

Mrigien, S. B. iii. 91, pl. 23, f. 25-28 (1822); Serville and St. Fargeat, Encycl. Meth. x. 437 (1825); Macquart, Dipt. Nord. Fr. iii. 88, part, pl. 2, f. 2 (1827); Mriges, S. B. vi. 344 (1830); Certis, Brit. Ent. viii. 397, part, (1832); MACQVART, Buff. i. 357, part, pl. 8, f. 12a (1834); ZETTERSTEDT, Lapp. jist (1838); LoEw, Progr. Posen (1840) 23. Isis, vii. 552 (1840); Zetrerstedt, I)ipt. Sc. i. 328 (1842); Boltard, Nouv. Man. iii. 325 (1843); Walker, List, iii. 511, part (1849); Zetrerstedt, Iipt. Sc. viii. 3012 (1849); S'Hol.7, Zts. Ent. Bresl. v. (19) 60 (1851); Walker, Ins. Brit. Dipt. i. 136 (1851); LoEw, N. Beitr. vi. 42 (1859); SChINer, F. A. Dipt. i. 9) (18(i2); J.'xdpeck, I)ipt. I)an. iii. 258, f. 116 (1910).

fascifemorata BRINETTI. Formosa BrovelTi, Re'c. Ind. Mus. ix. 38 (1913).

femorata, new name. Formosa femoralis Bezz, not Wheeler and Melaxdie, Ann. Mus. Hung. x. 480 and 483 (1912).

flavicornis, new speries. . . . . . . . . . . . . . . . . . . . . Panama 
flavipes Macquart, not Williston. . . . . . . . . . . . . . . . . . . . Europe

Macquart, Suit. a Buff. i. 357 (1834); Meigen, S. B. vii. 100 (1838); Bortard, Nouv. Man. iii. 325 (1843); Loew, N. Beitr. vi. 38 (1859); SCHIner, F. A. i. 95 (1862); Strobi, Mitth. Steierm. xxix. 108 (1892); BEZZ, Arch. Zool. Experim. Gen. (5) viii. 50 (1911).

? ambigua MacQuart, Dipt. France iii. 94 (1827) Platypalpus; Suit. Hist. Nat. i. 351 (1834); SCHINER, F. A. i. 92 (1862).

? curvipes MeIGEN, Syst. Bes. iii. 75 (1822) Tachydromia.

exilis 'MACQUaRT, part Dipt. France iii. 88 (1827).

fascipes Roser, Wurttemb. Correspbl. i. 54 (1840).

nigra Fallen, Dipt. Suec. Emp. 8 (1815) Tachydromia; Schiner, F. A. Dipt. i. 90 (1862) Platypalpus.

infumata, new species.

British Columbia

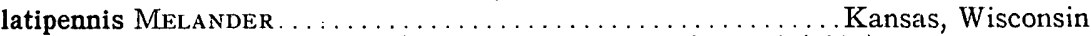

Melander, Tr. Am. Ent. Soc. xxviii. 209, pl. 5, f. 11, 19 (1902).

micropyga, new species........................ United States

mortua MEunier...................................... Amber

Meunier, Ann. Sci. Nat. Zool. vii, 97 (1908).

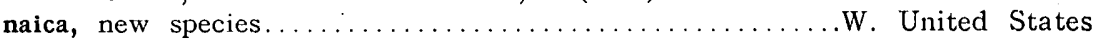

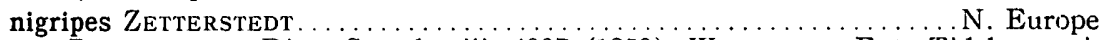

ZetTerstedT, Dipt. Scand. xiii. 4997 (1859); Wahlgren, Ent. Tidskr. xxxi. $87(1910)$.

pilosa, new species.......................... United States

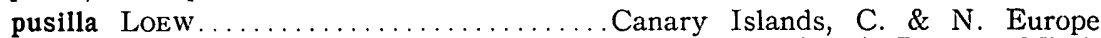

Loew, N. Beitr. vi. 36 (1859); Schiner, F. A. i. 96 (1862); Becker, Mittl. Zool. Mus. Berl. iv. 42 (1908); Strobl, Verh. Ges. Wien. lix. 179 (1909);

LundBeck, Dipt. Dan. iii. 259, f. 117 (1910); Dahl, Fauna Chorin, 465 (1912) Desc.; Frey Acta Soc. Fenn. xxxvii (3) 71 (1913) occ.

exilis ZetTerstedt, (not Meigen), Ins. Lapp. 554, 1, part (1838); Dipt. Scand. i. 328 (1842); viii. $3012(1849)$.

minima ZetTerstedt, not Meigen, Dipt. Scand. i. 327, 1. (1842).

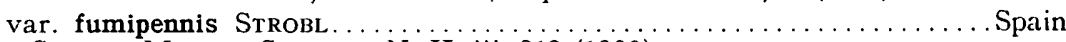

Strobl, Mem. r. Soc. esp. N. H. iii. 312 (1906).

rotundicornis BRUNETTI

BrunetTI, Rec. Ind. Mus. ix. 38 (1913).

rufipes BRUNETTI.

BrunetTi, Rec. Ind. Mus. ix. 38 (1913).

setulosa, new species.

W. North America

trichura, new species. Texas

xanthopyga BEzzI

N. Guinea

BEZZI, Ann. Mus. Nat. Hung. ii. 352, 33 (1904); x. 479 and 485 (1912).

B. Subgenus Eudrapetis, new subgenus.

ænea WALKER.

WALKER, Entom. v. 273, 45 (1871).

ænescens WIEDEMANN.

Europe, Africa

Wiedemann, Ausser, zweifl. Ins. ii. 649 (1830); Lorw, N. Beitr. vi. 35, (1859);

Dipterenf. Südafr. 270 (1860); SChiner, F. A. i. 96 (1S62); Giglic-Tos;

Ann. Soc. Ent. Fr. lxiv. 359 (1895); Becker, Mitth. Zool. Mus. Berl. ii.

40 (1902); Strobl, Glasnik $Z \in m$. Mus. Bosn. Herceg. xiv. 470 (1902);

Mitth. Bosn. Herceg. ix. 528 (1204); BezzI, Arn. N.us. Nat. Hung. ii. 351

(1904); Becker, Zts. Hym. Dipt. vii. 119 (1907); Bezzı, Ann. Mus. Hung. x. 479, 482 (1912); Suppl. Entom. iii. 75 (1914); Meijere, Tijd. Ent. lvi. suppl. 75 (1914).

brunnipes Macquart, Suit. a Buff. i. 358, (1834); Meicen, S. B. vii. 101, 6 (1838); LoEw, Progr. Posen (1840) 23: Isis vii. 552 (1840); Boltard, Nouv.

Man. iii. 325 (1843); Scholz, Zts. Ent. Bresl. v. (19) 60 (1851).

crassa LoEw, Ofvers. af $k$. Tet. Akad. Forhandl. xv. 341, 2 (1858). 
armata, new speecies.

United States

armipes BE\%:1.

Bkzz1, N. Acta Kais. Akad. xci 398, f. 18 (1909).

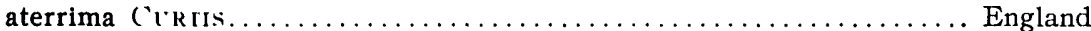

('TrTIs, Brit. Ent. 397 (1834); Walker, Ins. Brit. i. 136 (1851); Loew, N. Beitr. vi. 40, note (1859); Lunderck, I)ipt. I)an. iii. 254, f. 111-113 (1910); Frey, Acta Soc. Fenn. xxxvii (3) 68 (1913).

atra Walker, Ins. Brit. i. pl. 5, f. 3. (1851) no description.

nereosa Lotw, N. Beitr. vi. 37, (1859); Schiner, F. A. Dipt. i. 96 (1862).

nigritella ZetThestedt.............................. \& N. Europe Zet IERs TFIT, I)ipt. Scand. i. 298 (1842) Tachydromia.

brevis BEZZI.

Formosa

Blez:1, Ann. Mus. Hung. x. 480 and 483 (1912).

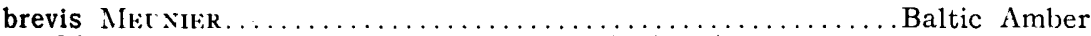

Mrixile, Ann. Soc. Sci. Nat. Zool. vii, 96 (1908).

decorata Mrisiter.

Metriter, Inn. Sci. Nat. Zool. vii, 96 (1908).

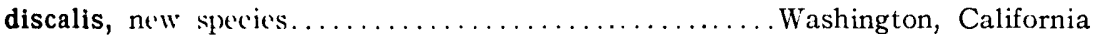

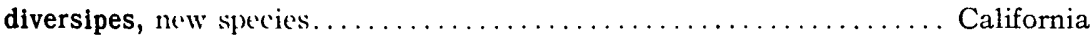

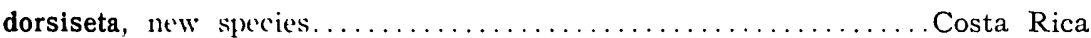

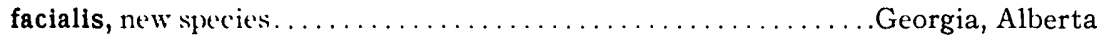

femoralis Whefler \& Melander....................... Vera Cruz, Tabasco

Wheel.er and Melander, Biol. C. Am. Dipt, i. 376 (1901); Melander, Trans. Am. Ent. Soc. xxviii. 211, f. 13 (1902); Bezz, N. Act. Kais. Akad. xci. $395(1909)$.

fortis BezzI

Blizz, N. Acta Kais. Akad. xci. 399 (1909).

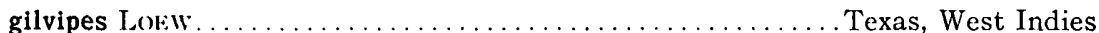
Loew, Berl. Ent. Zeitschr. xvi. 89: Cent. x. 61 (1872); Melander, Tr. Am.

Ent. Soc. xxviii. 213, 340 (1902); Bez.z, N. Act. Kais. Akad. xci. 397 (1909).

humilis Frivy

Frey, Acta Soc. Fenn. xxxvii (3) 69, f. 16-18 (1913).

inculta Coquillett. .......................... Texas, California

CoQlillett. Proc. U. S. Mus. xviii, 439 (1896) Platypalpus.

Melanier, Tr. Am. Ent. Soc. xxviii, 218 (1902).

inermis, new species.

Panama

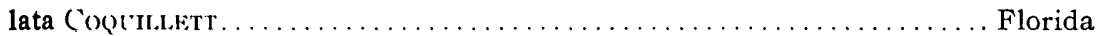

Coplillkt, Proc. Ent. Soc. Wash. v. 266 (1903) Tachydromia; Melander, Psyche, xvii, is1 (1910).

Loewi I AHI.

Germany

I) AHL, Fauna Chorin, 465 (1912).

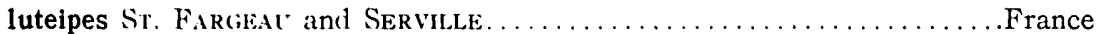
St. Farcieat and Serville, Encycl. Method. x. 437 (1825).

marginata Mriciks.

Mricies, Sýst. Be's. vii. 100 (1838).

E. Europe

medetera MiLANDER.

W. United States

Mlitanillir, Trans. Am. Ent. Soc. xxviii. 208, pl. v. f. 22 (1902); Ccovillett, Proc. Ent. Soc. Wash. v. 265 (1903) Elaphropeza; Melander, Ent. News, xvii, 372 (1906); Brzz., Ann. Mus. Nat. Hung. v. 567 (1967) Elaphropeza. 
moriella ZETTERSTEDT.

N. and C. Europe

ZETTERSTEDT, Ins. Lapp. 552 (1838) Tachydromia; Dipt. Sc. i. 299 (1842) Tachydromia; WahlgRen, Ent. Tidskr. xxxi. 86, f. 15 (1910).

curvinervis ZETTERSTEDT, Dipt. Sc. i. 301 (1842) Tachydromia.

flexuosa Loew, Progr. Posen, 1840, 23; Isis vii. 552 (1840); Scholz, Zts. Ent. Bresl. v. (19) 60 (1851); LoEw Neue Beitr. vi. 39 (1859); Schiner, F. A. Dipt. i. 96 (1862).

geniculata FalleN, Empid. 7, part (1815) Tachydromia.

nigra ZetterstedT. Dipt. Sc. i. 297 (1842) Tachydromia; Bonsdorf, Finl. tv. Ins. i. 150 (1861) Tachydromia.

picipes ZetTERSTEDT, Dipt. Sc. i. 298 (1842) Tachydromia.

var. setigera LoEw

Loew, Neue Beitr. vi. 39 (1859); Schiner, F. A. Dipt. i. 96 (1862); Lundbeck, Dipt: Dan. iii. 255, f. 114 (1910); FrEY, Acta Soc. Fenn. xxxvii (3) 70 (1913).

var. dilutipes STROBL.

Strobl, Mem. Soc. Esp. Hist. Nat. iii. 312 (1906).

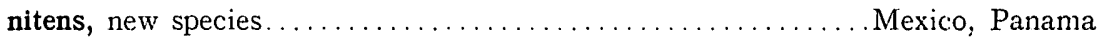
nuda, new species. . . . . . . . . . . . . . . . . . . . . . . . . .

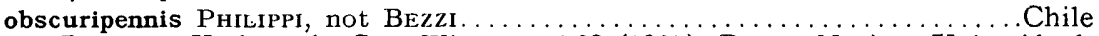

PhilıP , Verh. z. b. Ges. Wien. xv. 768 (1865); BezzI, N. Act. Kais. Akad. xci. 397 (1909).

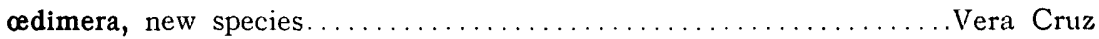

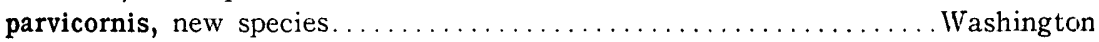

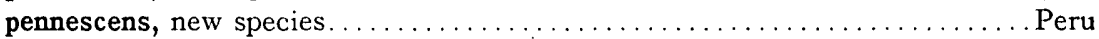

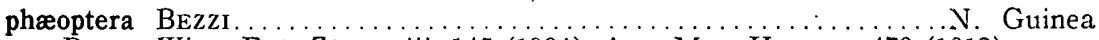

BeZzI, Wien. Ent. Ztg. xxiii. 145 (1904); Ann. Mus. Hung. x. 479 (1912).

obscuripennis Bezzi, not PhilipPi, Ann. Mus. Nat. Hung. ii. 351 (1904).

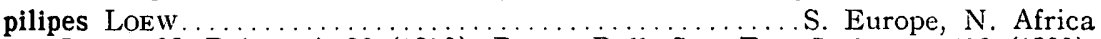

Loew, N. Beitr. vi. 36 (1859); BezzI, Bull. Soc. Ent. Ital. xxx. 152 (1899); Becker, Mittl. Zool. Mus. Berl. ii. 40 (1902).

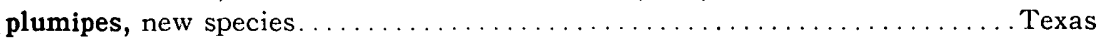

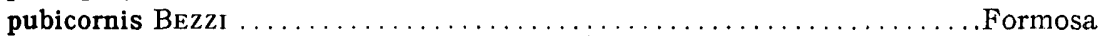

Bezzi, Ann. Mus. Hung. x. 479 and 482 (1912).

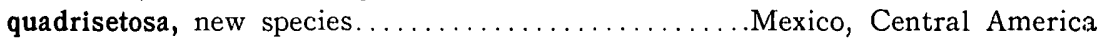

scissa, new species........................... United States

medetera Melander, part, Tr. Am. Ent. Soc. xxviii. 208, p1. 5, f. 22 (1902);

Coquillett Proc. Ent. Soc. Wash. v. 265 (1903) Elaphropeza; Melander,

Ent. News. 372 (1906); Bezzi, Ann. Mus. Hung. v. 567 (1907) Elaphropeza.

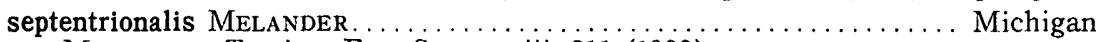
Melander, Tr. Am. Ent. Soc. xxviii. 211 (1902).

var. mexicana, new variety $\ldots \ldots \ldots \ldots \ldots \ldots \ldots \ldots \ldots \ldots$ Tampico

spectabilis MELANDER ......................... United States

Melander, Tr. Am. Ent. Soc. xxviii. 212, f. 9, 20 (1902).

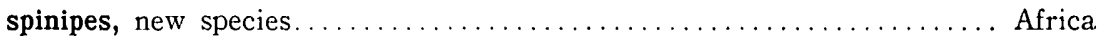

unipila LoEw .............................. United States

Loew, Berl. Ent. Zeitschr. xvi. 88, Cent. x. 60 (1872); Melander, Tr. Am.

Ent. Soc. xxviii. 211 and 339, f. 10, 14. 21 (1902); Ent. News, xvii. 372 (1906).

var. nitida MElander......................... United States Melander, Tr. Am. Ent. Soc. xxviii. 207, f. 10, 14, 21, and 339; Cole, Rept. Laguna Marine Lab. i. 152 (1912).

vitiosum Meunier........................................... Amber Meunier, Ann. Sci. Nat. Zool. 7, 96, pl. iii. f. 10-13 (1908)

xanthopoda Williston part..........................West Indies Williston, Tr. Ent. Soc. Lond. iii. 308, pl. iv. f. 85, part (1896); Melander, Tr. Am. Ent. Soc. xxviii, 212 and 340 (1902).

flavipes Williston, not MACQUART, Tr. Ent. Soc. Lond. iii. Apperdix, 441, table (1896); Melander, Tr. Am. Ent. Soc. xxviii. 212 (1902). 


\section{Subgenus Ctenodrapetis Bezzi.}

aristalis, new speries.

Philippine Islands

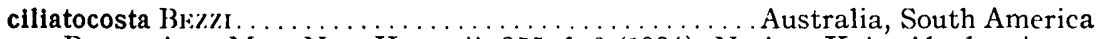
Br:zi, Ann. Mus. Nat. Hung. ii. 355, f. 6 (1904); N. Act. Kais. Akad. xci. 397 and 400 (1909); Ann. Mus. Hung. x. 481 (1912).

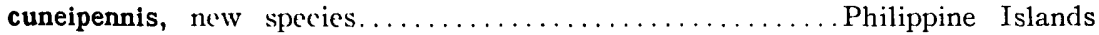
discoidalis BEzz. . . . . . . . . . . . . . . . . . . . . . . . . E. Indies Bezr., Ann. Mus. Nat. Hung. ii. 355 (1904); x. 482 (1912).

gracilis Bkzzr.................................... Guinea Brzzi, Ann. Mlus. Nat. Hung. ii. 354 (1904); x. 480 (1912).

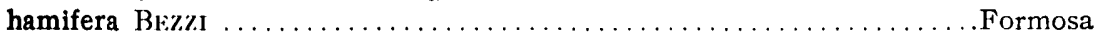
Bezzi, Inn. Mus. Hung. x. 479 and 485 (1912).

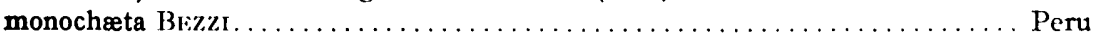

Brzz, N. Acta. Kais. Akad. xci. 401 (1909).

rubrithorax BEzZI.

Bkzzi, Ann. Mus. Nat. Hung. ii. 356 (1904); x. 482 (1912).

N. Guinea

strigifera MEIJERE.

Meijkre, Tijdschr. Ent. Liv. 333 (1911); lvi. suppl. 75 (1914).

valdiviana Puir.tpr. ..................................... Chile Philippi, Verh. Ges. Wien. xv. 768 (1865) Drapetis; Bezzi, N. Act. Kais. Akad xci. 397 (1909)? Ctenodrapetis.

\section{Subgenus Elaphropeza Macquart.}

abdominalis Wiedemañ .

China

Wibllmass, Aussereurop. Ins. ij. 12 (1830) Tachydromia; Bezzi, Ann. Mus. Hung. ii. 359, note (1904) Tachydromia; Melander, Psyche, xvii. 52 (1910) Ctenodrapetis.

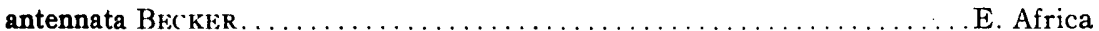

Becker, Bul. Mus. Paris 115 (1909); Ann. Soc. Ent. Fr. lxxix. 24 (1910); Bezz1, Ann. Mus. Hung. x. 481 (1912)

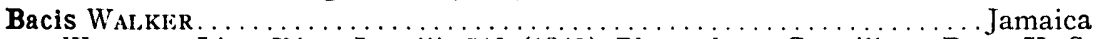

Walker, List. I)ipt. Ins. iii. 510 (1849) Platypalpus; Coquillett, Proc. U. S. Mus. xviii. 439 (1896) Tachydromia; Melander, Tr. Am. Ent. Soc. xxviii. 226 (1902) Tachydromia; BezzI, Ann. Mus. Hung. iii. 460 (1905) Tachypeza; N. Act. Kais. Akad. xci. 402, note (1909); Melander, Psyche, xvii. 52 (1910) Ctenodrapetis.

basalis Brz.z. . . . . . . . . . . . . . . . . . . . . . . . . . . . . . . . . . Ceylon Bะrz, Ann. Mus. Hung. ii. 349 (1904); v. 567 (1907); x. 479 (1912).

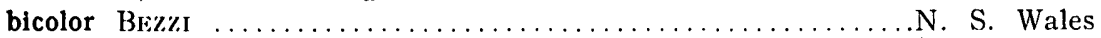
BkzzI, Ann. Mus. Hung. ii. 349 (1904); v. 567 (1907); x. 482 (1912).

bicoloripes Brivetti.......................... Himalayas Brinetti, Rec. Ind. Mus. ix. 43 (1913).

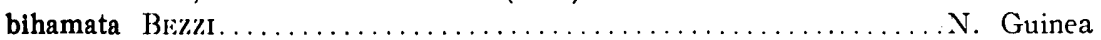
Br:zi, Ann. Mus. Nat. Hung. ii. 353 (1904) Drapetis.

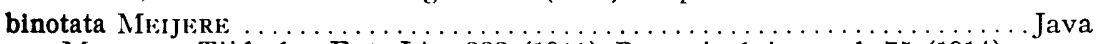
Meijbre, Tijdschr. Ent. Liv. 333 (1911) Drapetis; lvi. suppl. 75 (1914).

calcarifera Brzz. ................................ Formosa Bে:zz, Ann. Mus. Hung. v. 267 and 268 (1907); x. 481 and 488 (1912).

callositibia Bezzı. . . . . . . . . . . . . . . . . . . . . . . . . . Guinea Brzz, Ann. Mus. Nat. Hung. ii. 354 (1904) Drapetis; x. 480 (1912) Drapetis.

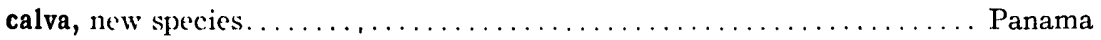

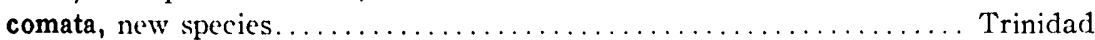


dispar ADAMS Rhodesia

Adams, Kans. Univ. Sci. Bul. iii. 157 (1905); BezzI, Ann. Mus. Hung. v. 567 $(1907) ; x .480$ (1912).

ephippiata FaLLEN.

Europe

FAllen, Empid. 11 (1815) Tachydromia; Meigen, Syst. Bes. iii. 65, pl. 23, f. 10 (1822) Hemerodromia; MacQuart, Dipt. Nord. Fr. iii. 87, pl. 2, f. 1 (1827); Hist. Nat. i. 359, pl. 8, f. 14a (1834); ZetTerstedt, Dipt. Sc. i. 326 (1842); BoITARD, Nouv. Man. iii. 325 (1843); Walker, List. iii. 505 (1849); Ins. Saunders. i. 134, pl. 5, f. 4 (1851); Scholz, Zts. Ent. Bresl. v. 60 (1851) (ephippium); Schiner, F. A. Dipt. i. 95 (1862); Strobl, Mitth. Steierm. xxix. 127 (1892); Melander, Ent. News, xvii. 372 (1906) Drapetis; Bezzi, Ann. Mus. Hung. v. 567 (1907); LundBeck, Dipt. Dan. iii. 273, f. 123, 124 (1910); Wahlgren, Ent. Tidskr. xxxi. 89 (1910); Bezzi, Ann. Mus. Hung. x. 482 (1912); Frey, Acta Soc. Fenn. xxxvii. (3) 75 (1913).

? maculata MacQUaRT, Mem. Soc. Sci. Lille, 153 (1823) Tachydromia.

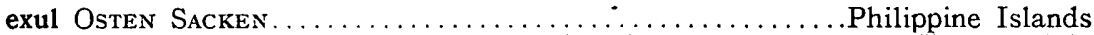

Osten SaCken, Berl. Zts. xxvi. 113 (1882); Bezzi, Ann. Mus. Hung. ii. 347; (1904); v. 567 (1907); x. 480 (1912) Drapetis.

ferruginea BRUNETTI

BrUNetTI, Rec. Ind. Mus. ix. 43 (1913).

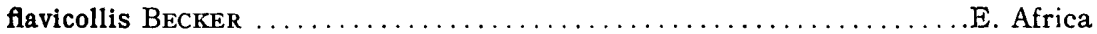

Becker, Bull. Mus. Paris 116 (1909) Drapetis; Ann. Soc. Ent. Fr. lxxix. 24 (1910) Drapetis; Bezzi, Ann. Mus. Hung. x. 482 (1913).

flavida Williston ....................... Indies, C. and S. America

Williston, Trans. Ent. Soc. Lond. iii. 308, pl. 11, f. 86 (1896) Drapetis; Coquilletr, Proc. U. S. N. Mus. xxii. 251 (1900) Tachydromia; Wheeler \& Melander, Biol. C. Am. Dipt. i. 376 (1901) Drapetis; Melander, Mon. Empid. 213 (1902) Drapetis; Coquillett, Proc. Ent. Soc. Wash. v. 265 (1903) Tachydromia; Bezzr, N. Act. Kais. Akad. xci. 397 and 398 (1909) Drapetis; Melander, Psyche, xvii. 52 (1910) Ctenodrapetis; 1910; BezzI, Ann. Mus. Hung. x. 481 (1912).

fulvida BEZzI, Wien. Ent. Ztg. xxiii. 144 (1904) Tachista.

xanthopoda Wrtciston part, Tr. Ent. Soc. Lond. iii. Appendix, 441, table (1896) Drapetis.

formosæ BEzzI. Formosa

Bezzr, Ann. Mus. Hung. v. 566 (1907); x. 480 and 487 (1912).

fulvithorax v. D. WuLP . . . . . . . . . . . . . . . . . . . . . . Ceylon

WulP, Termes, Fuzet. xx. 138 (1897); Tijdschr. Ent. xlii. 49 (1899); BEzzI, Ann. Mus. Hung. ii. 347 (1904); v. 567 (1907); x. 480 (1912); MeIJere, Tijd. Ent. lvi. suppl. 73 (1914).

hirsutitibia MEIJERE.

MeiJere, Tijd. Ent. lvi. suppl. 73 (1914).

bihamata MeIJere, not BezzI, Tijd. Ent. liv. 332 (1911) Drapetis.

inflexa, new species. . . . . . . . . . . . . . . . . . . . . . . . . . . . . .

Kerteszi BezzI ...................................... Formosa

Bezzi, Ann. Mus. Hung. x. 481 and 486 (1912); Merjere, Tijd. Ent. lvi. suppl. 74. (1914).

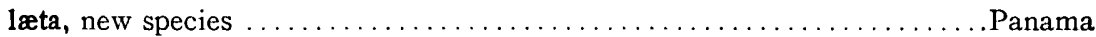

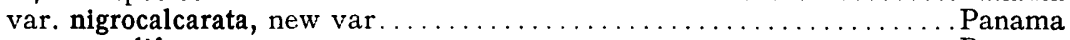

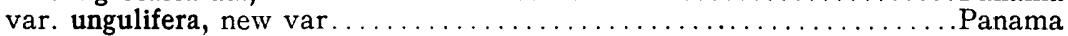

lanuginosa BEzzI

Formosa

BEzzI, Suppl. Entom. iii. 75 (1914).

lineola MEIJERE

MeIJERE, Tijdschr. Ent. liv. 331 (1911); 1vi. suppl. 75 (1914).

Java

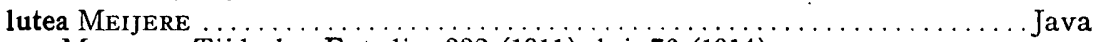
MeIjere, Tijdschr. Ent. liv. 332 (1911); lvi. 76 (1914).

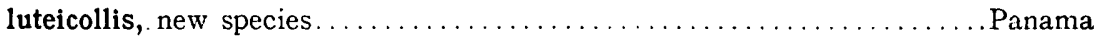




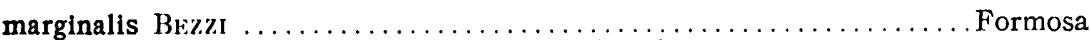
Brzz, Ann. Mus. Hung. x. 481 and 489 (1912).

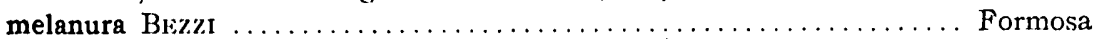

Bez..I, Ann. Mus. Hung. x. 481 and 489 (1912).

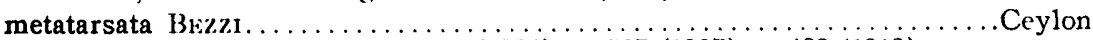

Bezzi, Ann. Mus. Hung. ij. 348 (1904); v. 567 (1907); x. 482 (1912).

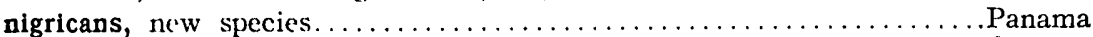

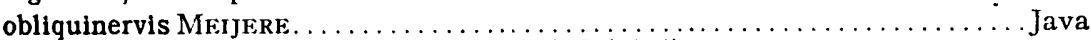
Mkijere, Tijil. Ent. suppl. 73, pl. 2, f. 9 (1914).

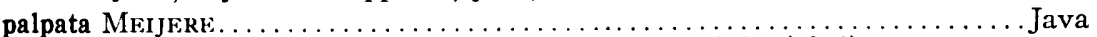
Meijere, Tijilschr. Ent. liv. 330 (1911); 1vi. suppl. 76 (1914).

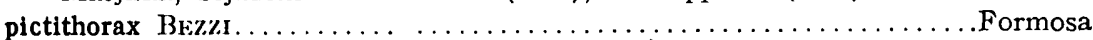
BezzI, Ann. Mus. Hung. x. 482 and 486 (1912).

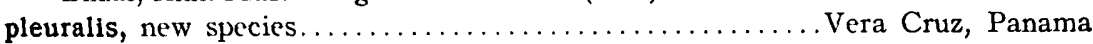

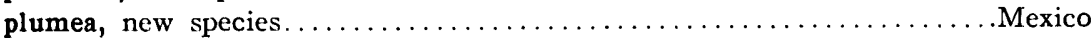

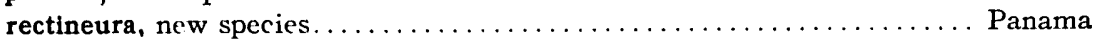

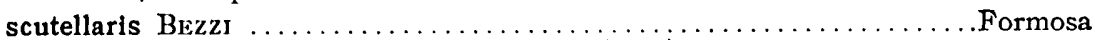

Bezzi, Ann. Mus. Hung. x. 481, 482, 487 (1912).

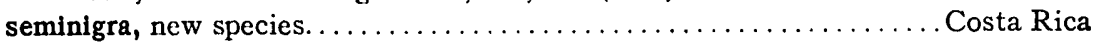

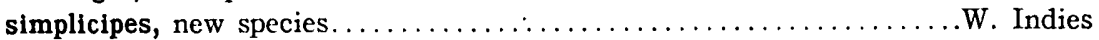

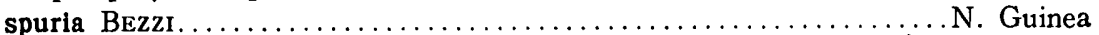

BezzI, Ann. Mus. Hung. ii. 347 (1904); v. 567 (1907); x. 480 (1912).

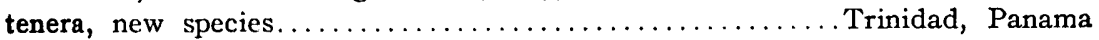

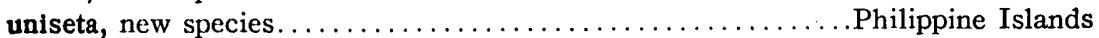

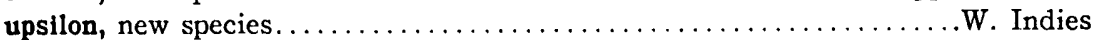

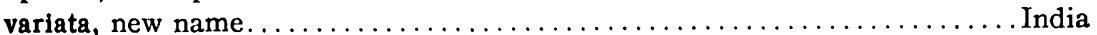
variegata BRUNETTI (bis) Rec. Ind. Mus. ix. 42 (1913).

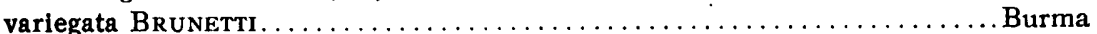
BRUNETTI, Rec. Ind. Mus. ix. 39 (1913) Drapetis.

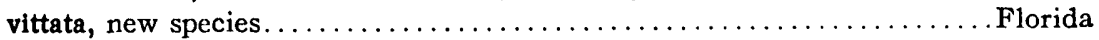

xanthocephala Bezzi. . . . . . . . . . . . . . . . . . . . . Formosa

BEzzi. Ann. Mus. Hung. x. 481 and 488 (1912). 